\title{
Influence of weathering process on small-strain shear modulus (Gmax) of hydrocarbon-contaminated sand
}

DOI:

10.1016/j.soildyn.2018.01.006

\section{Document Version}

Accepted author manuscript

Link to publication record in Manchester Research Explorer

\section{Citation for published version (APA):}

Rajabi, H., \& Sharifipour, M. (2018). Influence of weathering process on small-strain shear modulus (Gmax) of hydrocarbon-contaminated sand. Soil Dynamics and Earthquake Engineering, 129-140.

https://doi.org/10.1016/j.soildyn.2018.01.006

\section{Published in:}

Soil Dynamics and Earthquake Engineering

\section{Citing this paper}

Please note that where the full-text provided on Manchester Research Explorer is the Author Accepted Manuscript or Proof version this may differ from the final Published version. If citing, it is advised that you check and use the publisher's definitive version.

\section{General rights}

Copyright and moral rights for the publications made accessible in the Research Explorer are retained by the authors and/or other copyright owners and it is a condition of accessing publications that users recognise and abide by the legal requirements associated with these rights.

\section{Takedown policy}

If you believe that this document breaches copyright please refer to the University of Manchester's Takedown Procedures [http://man.ac.uk/04Y6Bo] or contact uml.scholarlycommunications@manchester.ac.uk providing relevant details, so we can investigate your claim.

\section{OPEN ACCESS}




\title{
Influence of weathering process on small-
}

\section{strain shear modulus $\left(G_{\max }\right)$ of hydrocarbon-}

\section{contaminated sand}

\author{
Hamid Rajabi*, Mohammad Sharifipour
}

Department of Civil Engineering,

Faculty of Engineering, Razi University, Kermanshah 67149-67346, Iran

* Corresponding author

Tel.: +98 8334274535

E-mail: ham.rajabi@gmail.com

hamid_rajabi@razi.ac.ir 


\section{Abstract}

The engineering characteristics of hydrocarbon-contaminated soils have been precisely concentrated so far. However, besides influential effects of weathering on hydrocarboncontaminated soils, a substantial majority of these studies have been devoted to short-term analyses. By the same token, the present paper aims at comparing short- and long-term effects of light crude oil contamination on maximum shear modulus $\left(\mathrm{G}_{\max }\right)$ of two sand (Ottawa and Firoozkooh sand). To this aim, a series of bender element tests was conducted on both newly and aged contaminated sand samples under identical circumstances so as to characterize short- and long-term influences of the hydrocarbon contamination on $G_{\max }$. In the short term, $G_{\max }$ of Firoozkooh sand was more sensitive to the contamination compared to Ottawa sand; however, the tendency of their responses was almost similar so that presence of 4 wt.\% of crude oil into both sand types could greatly increase the value of $G_{\max }$, and adding further contamination made markedly negative changes in $G_{\max }$ to some extent that $G_{\max }$ of both 8 wt.\% contaminated sand types was lower than that of clean ones. Furthermore, $G_{\max }$ of both sand types were not sensitive to adding more crude oil ( $\geq 8 \mathrm{wt} . \%)$. Generally, in the long term, weathering process could obviously increase the value of $G_{\max }$ of both sand types such that the changes were more detectable during the first 6 months, and more importantly, the majority of these alterations took place in the first 2 months. Additionally, in contrast to short-term findings, contaminated Ottawa sand samples were more sensitive to weathering process, and the degree of weathering effects on $\mathrm{G}_{\max }$ was more observable in $4 \mathrm{wt} . \%$ contaminated samples of both sand types in comparison with specimens containing 8 and 12 wt.\% of crude oil.

Keywords: Hydrocarbon contamination; Small-strain shear modulus; Ottawa sand; Firoozkooh sand; Bender element test 


\section{Introduction}

Heretofore, hydrocarbon contamination of soils has attracted considerable attentions due to its significant environmental and/or engineering aftereffects on our surroundings as well as its everincreasing rate of occurrences [1]. Beside harmful environmental impacts of hydrocarbon-based contaminants on our ecosystem, the consequences of unintentionally and/or consciously releasing this type of pollutants on physical, chemical, and engineering properties of soils have been still a matter of debate as a result of its noticeable significance in geotechnical applications [2-5]. By the same token, various research endeavours have been made to examine effects of hydrocarbon contamination on geotechnical properties of soils, and meanwhile, influences of a wide range of hydrocarbon compounds on geotechnical characteristics of both fine- and coarsegrained soils have been taken into consideration in the relevant literature. In a general view, the natural and/or artificial emissions of various kinds of hydrocarbons into soils have been concentrated by several researchers so far which can be grouped as heavy/light crude oil $[2,3,5$ 13], used engine oil [14-17], lamp oil [18], diesel [15, 19-21], gasoline [15, 22], palm biodiesel [23], used motor oil [11, 24-28], bitumen [29], benzene [2, 30], and gas oil [27, 31, 32]. According to a comprehensive review done by the authors on approximately all relevant written articles with the scope of geotechnical properties of hydrocarbon contaminated soils, it can be concluded that a variety of geotechnical characteristics of these contaminated soils has been focused in the literature so far including soil grain size distribution [2, 12, 25, 26, 28, 33-35], Atterberg limits $[3,4,8,12,19,21,26,31,32,34,36]$, permeability [2, 3, 15-17, 33, 37-41], optimum moisture content $[4,7,9,11,12,17,19,21,25,28,29,32-36,40,42-45]$, maximum dry density $[2,3,8,11,12,19,21,33,36,40,44,46]$, consolidation properties $[2,15,22,26,28$, $31,32,35,44,47,48]$, angle of internal friction $[2,3,7,12,15,16,18,24,46]$, cohesion $[3,11$, 
$16,31,34]$, and etc. For the most part, their findings about a particular soil property were in an acceptable agreement; however, in some specific cases, there has been a great deal of conflicts among their results which can be reasonably justified with reference to existing differences in soil and/or in hydrocarbon types as well as in the specific nature of the considered property.

As an overall analysis and based on the literature review, there has not been an extensive experimental study concentrating on long-term influences of hydrocarbon contamination on small-strain shear modulus $\left(G_{\max }\right.$ or $\left.G_{0}\right)$ of soils. In this regard, it could be beneficial to study long-term behaviour of hydrocarbon-contaminated soils in terms of small-strain shear modulus due to this point that the exposure of hydrocarbon contaminated soils to the influences of surrounding conditions would make obvious changes in geotechnical properties of hydrocarbon contaminated soils [30]. Therefore, the proposed idea could have its own advantages due to this point that small-strain shear modulus $\left(G_{\max }\right.$ or $\left.G_{0}\right)$ of soils is an applicable and fundamental characteristic in small/very small strain geotechnical applications including machine foundation performance, deep excavation design, and earthquake ground response analysis [49, 50]. As a theoretically confirmed fact in wave propagation phenomenon at small-strain circumstances, maximum shear modulus of a soil can be measured by the use of shear wave velocity travelling through the soil via $G_{\max }=\rho V_{s}^{2}[49,51]$. According to the relevant literature, there are various experimental methods determining shear wave velocity of soils such as bender element (BE) system, resonant column (RC) apparatus, and torsional shear (TS) test [52]. Meanwhile, bender element test as a simple, rapid, and non-destructive appliance is compatible to be assembled into the other common geotechnical testing apparatus like triaxial tests. Moreover, bender elements have been employed by geotechnical engineers separately and/or simultaneously with the other similar testing equipment like resonant column and torsional shear test to determine shear wave 
velocity in soil samples [52-55]. In this study, the authors have aimed at experimentally examining long-term influences of hydrocarbon contamination on small-strain shear modulus of sandy soils. To this end, two types of silica sand, Ottawa sand and Firoozkooh sand, were selected as basic materials, and a kind of Iranian light crude oil was chosen as a hydrocarbon contaminant. Moreover, a bender element system was used so as to evaluate short- and long-term $\mathrm{G}_{\mathrm{max}}$ of both contaminated sand types. It should be noted here that all clean and contaminated sand specimens were prepared under similar circumstances with an almost identical void ratio, and additionally, the whole testing procedures for clean and fresh/aged contaminated samples were carried out based on a completely similar approach. Equally important, a series of resonant column tests was separately conducted on an oven-dried specimen of both sand types under the same conditions to the bender element test in order to validate both testing method and analytical procedure used in this study.

\section{Materials and methods}

\subsection{Sand}

In this research, two types of sand, Ottawa and Firoozkooh sand, has been used as host materials to hydrocarbon contamination. The Ottawa sand had naturally light yellow grains which were approximately formed of purely quartz substances, and provided by Amitis Azma Company, Iran. Based on particle size distribution (PSD) analyses (Fig. 1), PSD curve of the used Ottawa sand was suitably placed within the defined boundaries by a relevant literature defining standard Ottawa sand [56]. Moreover, basic properties of the used Ottawa sand $\left(G_{s}, D_{10}, D_{60}, D_{30}, C_{u}, C_{c}\right)$ have been listed in Table 1, and accordingly, it can be said that characteristics of the used Ottawa sand were also between those of standard Ottawa sand with the exception of the coefficient of 
curvature $\left(\mathrm{C}_{\mathrm{c}}\right)$ [56]. To add to that, chemical composition of the used Ottawa sand provided by the supplier showed that more than 97 percent of solid volume of the used Ottawa sand was silica (silicon dioxide $\left(\mathrm{SiO}_{2}\right)$ ). Consequently, it can be inferred here that the used Ottawa sand (hereafter Ottawa sand) has been in an adequate compliance with the relevant standard [56]. On the other hand, Firoozkooh Sand No. 151 (henceforth Firoozkooh sand) was chosen in this study as natural silica sand, and was provided by Silica Sand MFG Company of Iran. In this connection, natural sand samples were collected by the company from particular mines near Firoozkooh city, northeast of Tehran province, Iran. PSD curve and basic properties of Firoozkooh sand have been also presented in Fig. 1 and Table 1, respectively, along with those of Ottawa sand.

\subsection{Hydrocarbon contaminant}

As a hydrocarbon-based contaminant, an appropriate amount of Iranian light crude oil was provided by West Oil and Gas Production Company (WOGPC) of Iran. According to an analytical study conducted by the supplier, specific gravity, American Petroleum Institute gravity (API gravity), salt content and $\mathrm{H}_{2} \mathrm{~S}$ concentration of the crude oil was about $0.888,28,34 \mathrm{gr} / \mathrm{m}^{3}$, and $22 \mathrm{ppm}$, respectively,

\subsection{Scanning electron microscopy (SEM)}

In this study, a series of SEM images captured by a scanning electron microscopy apparatus (KYKY - EM3200, China) at 26000 Volt with a scale bar of 10 and 100 um and various magnifications has been employed to evaluate effects of weathering phenomenon on microstructure of hydrocarbon-contaminated sand. 


\subsection{Test equipment}

A digitally controlled triaxial testing apparatus (STRASSENTEST OHG Company, Germany) equipped with a bender element system (provided by Soil Mechanics Industry of Iran (SMI)) was used in this study. The used bender elements were $22.15 \mathrm{~mm}$ in width, $3.80 \mathrm{~mm}$ in thickness, and $10.90 \mathrm{~mm}$ in the protruding depth, and assembled with a configuration of bottom-fixed/top-free (Fig. 2). Sinusoidal shear waveforms were used in this research with a frequency range of 4-20 $\mathrm{kHz}$ and an amplitude of $22 \mathrm{mV}$. In primary calibration BE tests, the delay times originated from wiring connections between the used apparatus were determined at different frequencies under a configuration of straightforward tip-to-tip attached bender elements, and considered in relevant calculations. Furthermore, vertical displacements of the samples were considered as the only index evaluating volume changes in the present study. In addition to the BE tests, a resonant column (RC) apparatus (Seiken, Inc., Japan) at International Institute of Earthquake Engineering and Seismology of Iran (IIEES) was used to select the most accurate methods of determining shear wave arrival time in $\mathrm{BE}$ tests. In this regard, both $\mathrm{BE}$ and $\mathrm{RC}$ tests were conducted on similar oven-dried samples of both sand types.

\subsection{Sample preparation and testing procedure}

Initially, all sand specimens were kept in an oven for about 48 hours to prepare completely ovendried samples. After being cooled down in insulated containers, uniformly contaminated specimens were prepared using a soil stirring device. In this regard, 4, 8, 12 wt.\% of light crude oil were considered as influential amounts of hydrocarbon contamination cited in the relevant literature. Then, the contaminated sand samples were kept in the sealed plastic containers for at least 3 days under normal circumstances to attain an acceptable state of homogeneity. 
Afterwards, the provided contaminated samples were experimented for short-term analyses, however, adequate amounts of the contaminated sand of all percentages were exposed to natural surrounding conditions outside the lab, and the samples were continuously weighted at least once a week to determine mass loss due to oil evaporation. To provide an acceptable/reasonable level of comparison, all fresh and aged contaminated specimens along with clean samples were prepared under comparable circumstances (void ratio $\cong 0.715$ ). To this aim, dry and quasi-moist tamping method were utilized to prepare clean and fresh/aged contaminated sand samples [54, 57]. In the dry tamping method, to create a 5-layer cylindrical sand specimen [58], a suitable amount of clean sand sample was poured into the mold as the first layer by the use of a plastic funnel (nozzle diameter of $7.0 \mathrm{~mm}$ ) with no falling gap. Then, the layer surface was simultaneously compacted by a 650 -gr aluminum pounder (diameter of $85 \mathrm{~mm}$ ) and leveled by an absolute digimatic caliper to guarantee approaching a proper void ratio in the layer. Afterwards, the layer surface was roughened by a mild flat brush to create an influential interfacial roughness between layers. Accordingly, this procedure was repeated for the next layers with some differences in compactive efforts to provide specific conditions of dry tamping method $[54,57,58]$. Regarding fresh and aged contaminated sand specimens, it should be stated that sample preparation (quasi-taming method) was similar to the dry tamping method with some minor differences in compactive efforts and sample height to achieve an identical void ratio. Table 2 provides brief information with regard to the prepared clean and contaminated specimens. Thereafter, the top-free bender element was assembled using a well-fitting o-ringed head (and bottom), and a sufficient amount of suction (10-30 kPa) was implemented using a lab scale vacuum pump to hold the specimen in a vertical direction so that a similar initial polarization in the recorded wave signal was achieved. In Fig. 3, images of the prepared clean 
and contaminated samples along with a graphical illustration of a specimen were provided. To prevent samples from being shocked, the imposed suction was gradually omitted during the first step of confinement. In all experiments, vertical displacements of specimens measured by LVDT was used to correct tip-to-tip distance between the elements.

\subsection{Determination of shear wave arrival time}

In geotechnical applications, shear wave velocity $\left(\mathrm{V}_{\mathrm{s}}\right)$ of soils is an influential and functional parameter due to this fact that in small/very small strain circumstances maximum shear modulus of soils $\left(G_{\max }\right.$ or $\left.G_{0}\right)$ can be calculated using $V_{s}$ through $G_{\max }=\rho V_{s}^{2}$ where $\rho$ is soil density [52]. Generally speaking, in a bender element test, it is usually tried to transmit a clear-cut shear wave signal using an element and to record the corresponding received signal at another element in order to determine shear wave arrival time $\left(\mathrm{T}_{\mathrm{s}}\right)$ and shear wave travel distance $\left(\mathrm{L}_{\mathrm{s}}\right)$, thereby enabling the user to measure shear wave velocity $\left(\mathrm{V}_{\mathrm{s}}=\mathrm{L}_{\mathrm{s}} / \mathrm{T}_{\mathrm{S}}\right)$. In this regard, almost in all relevant literature $[50,52,55]$, shear wave travel distance $\left(L_{s}\right)$ has been assumed to be identical to tip-to-tip distance between bender elements as the shortest direct space between the elements in a BE system. Most importantly, it should be noted here that, as it was considered in this study, any alteration in the distance between $\mathrm{BE}$ elements must be taken into consideration in calculation of shear wave velocity. Having frequently stated in the relevant literature [52], the determination of shear wave arrival time in BE tests has always been accompanied by a state of uncertainty. Indeed, propagation of a shear wave signal generated by a transmitter element in a BE system might be along with a boundary-induced compression wave so that a combination of these signals would lead to a complicated situation in the receiver element at specific conditions, thereby making it an elaborate task to determine the accurate shear wave arrival time (see also 
Fig. 3(a)). This probable condition was named as near-field-effect (NFE), and the NFE has been more often detected in soils under a dry condition as a result of smaller differences between velocity of shear and compression wave in soils with a negligible amount of moisture [51]. In addition, the NFE as a dispersive phenomenon is a frequency-dependent issue, and might be alleviated or intensified at particular excitation frequencies [59]. By the same token, a geometric recommendation was proposed by Jovicic et al. [60] and adopted by Brignoli et al. [61] and Lo Presti et al. [62] upon which the degree of NFE might be controlled and/or weakened by the ratio of $R_{d}=L_{s} / \lambda_{s}$ where $L_{s}$ and $\lambda_{s}$ are shear wave travel distance and wavelength, respectively. Accordingly, the NFE was obviously detected for the amounts of $\mathrm{R}_{\mathrm{d}}$ between 0.25 and 4 , and particularly close to 1.0 . However, in the cases of $R_{d} \geq 4.0$, the NFE symptoms were greatly weakened, and it was possible to determine shear wave arrival time $\left(\mathrm{T}_{\mathrm{s}}\right)$. To add to that, Sanchez-Salinero proposed to conduct bender element tests with $\mathrm{R}_{\mathrm{d}}$ equal to 2.0 so as to suitably control the NFE [63]. Moreover, Arroyo et al. [64] and Leong et al. [65] have also suggested considering the value of $\mathrm{R}_{\mathrm{d}}$ higher than 1.60 and 3.33, respectively, in order to lessen the influences of near-field phenomenon on bender element results. Due to this reason that the NFE can be influenced by both excitation frequency and materials properties, in this study, a primary experimental survey was carried out to conduct a series of BE tests on both clean oven-dried Ottawa and Firoozkooh sand which the results can be found in Fig. 4 and Fig. 5, respectively. To this end, clean samples of both sand types were experimented by the BE system under confining pressure of $\sigma_{3}=300 \mathrm{kPa}$ and $\mathrm{e}_{0}=0.715$ at various frequencies $(4-20 \mathrm{kHz})$. This range of excitation frequency was chosen to evaluate effects of frequency on the NFE since the degree of NFE might increase again at higher frequencies than $20 \mathrm{kHz}$ as a result of this fact that the compression wave signals can be reduced at higher frequencies; however, the degree of reflected 
shear wave signals may be rose again, thereby intensifying the NFE event [54]. In Fig. 4 and Fig. 5 , it can be observed that the arrivals of received signals at higher frequencies $(\geq 8 \mathrm{kHz})$ are much more distinguishable rather than at lower ones as a results of NFE influences [65]. Equally important, shear wave arrival times measured by a series of RC tests on both Ottawa and Firoozkooh sand samples under identical circumstances $\left(\sigma_{3}=300 \mathrm{kPa}\right.$ and $\left.\mathrm{e}_{0}=0.715\right)$ were also provided as dotted lines in Fig. 4 and Fig. 5, respectively. At higher frequencies, also, the agreement between $\mathrm{BE}$ and $\mathrm{RC}$ results is detectable.

In general, several methods have been employed in the relevant literature so as to detect shear wave arrival time in BE tests including temporal and mathematical methods $[50,55]$. In temporal methods, the user should detect specific points on transmitted and received signals of waves in a BE system (i.e. peaks and first arrivals) and measure some shear wave arrival times like start-tostart $\left(\mathrm{T}_{\mathrm{ss}}\right)$ and peak-to-peak $\left(\mathrm{T}_{\mathrm{pp}}\right)$. The temporal methods may be intrinsically led to various shear wave arrival times, and in order to tackle this situation and to achieve a more precise arrival time, an alternative mathematical method based on the concept of cross-correlation function has been used by the researchers in this field. Firstly developed by Viggiani and Atkinson in 1995 in order to analyse bender element tests and initially employed by Mancuso et al. in 1989 to evaluate cross-hole test results $[50,66]$, the time corresponding to maximum of cross-correlation function $\left(\mathrm{T}_{\mathrm{cc}}\right)$ applied to transmitted and received wave signals in a BE test result could be an accurate shear wave arrival time [55].

In Fig. 6, a typical signal of a transmitted shear wave and of the corresponding received wave as well as the resultant curve of cross-correlation function applied to both transmitted and received signals have been presented. According to the temporal and mathematical methods, several specific points on both typical transmitted and received signals in Fig. 6 could be distinguished 
by the authors including A and B on the transmitted shear wave, $\mathrm{C}$ on cross-correlation curve, and $\mathrm{D}, \mathrm{E}, \mathrm{F}$, and $\mathrm{G}$ on the received signal. Accordingly, different arrival times such as $\mathrm{T}_{\mathrm{AD}}, \mathrm{T}_{\mathrm{AE}}, \mathrm{T}_{\mathrm{AF}}$, and $\mathrm{T}_{\mathrm{AG}}$ as start-to-start arrival times, $\left(\mathrm{T}_{\mathrm{BG}}\right)$ as a peak-to-peak arrival time, and $\mathrm{T}_{\mathrm{cc}}$ as the peak of cross-correlation function can be defined.

In a more detailed manner, it can be theoretically stated that all of predefined start-to-start arrival times (SS) including $\mathrm{T}_{\mathrm{AD}}, \mathrm{T}_{\mathrm{AE}}$, and $\mathrm{T}_{\mathrm{AF}}$ would be a probable accurate shear wave arrival time in a BE system. However, by referring to the relevant results of RC tests (Fig. 4 and Fig. 5), it can be inferred that arrival times measured by the points of $\mathrm{D}$ and $\mathrm{E}$ would not present an exact arrival time as a result of this fact that these points might be influenced by the NFE, especially at lower excitation frequencies. Hence, $\mathrm{T}_{\mathrm{AF}}, \mathrm{T}_{\mathrm{BG}}$, and $\mathrm{T}_{\mathrm{cc}}$ were considered as start-to-start (SS), peak-topeak (PP), and cross-correlation (CC) arrival times in this study.

In order to evaluate efficiency of both temporal and mathematical methods to detect accurate shear wave arrival times in various BE conditions, it has been tried in Fig. 7 to accumulate the determined arrival times by the $\mathrm{BE}$ system under confining pressure of 100,300 , and $500 \mathrm{kPa}$ as well as at all frequencies $(2,4,6,8,10,12,14,16,18$, and $20 \mathrm{kHz})$ along with arrival times obtained by RC tests under similar circumstances. In general, shear wave arrival times of Firoozkooh sand were moderately lower than those of Ottawa sand. This observation could be associated with the existing differences in grain size and structure of both sands (Fig. 1) which might be led to various shear wave velocities. However, in higher levels of confinement $(\geq 300$ $\mathrm{kPa}$ ), the considerable adaptation can be found among shear wave arrival time of both sand types. This trend might be related to this fact that both sand kinds achieved an almost similar grain interlocking at higher confining pressures. Moreover, the tendency of curves in the case of Ottawa sand in Fig. 7(a) has followed an almost similar path for all $\mathrm{T}_{\mathrm{ss}}, \mathrm{T}_{\mathrm{pp}}$, and $\mathrm{T}_{\mathrm{cc}}$ at each 
confining pressure; however, in the case of Firoozkooh sand, a slight state of scattering can be seen in the data in some points. Based on the relevant results of RC tests which were embedded in Fig. 7, it can be inferred that, for both sand types, the determined shear wave arrival times by $\mathrm{RC}$ tests were slightly higher than those detected by BE tests in similar conditions, especially in higher levels of confinement, and more importantly, this matter was much observable in the case of Firoozkooh sand. Furthermore, for both sands and in all confining pressures, as excitation frequency increased in the BE tests, the curves of arrival time were not perceptibly sensitive to the excitation frequency such that, for higher frequencies $(\geq 8 \mathrm{kHz})$, the adaptations among the results of $\mathrm{BE}$ and $\mathrm{RC}$ results approached such a level enabling the authors to define a consistency range (Fig. 7). It is worth noting that the ratio of $R_{d}$ throughout the defined consistency range was higher than its previously mentioned criteria which were also provided in Fig. 7 as vertical short lines. As an overall analysis, hereafter in this study, arrival times determined by start-tostart and cross-correlation method were considered in the analytical procedure.

\section{Results and discussion}

\subsection{Short-term analysis}

To evaluate short-term influences of crude oil contamination on small-strain shear modulus of sandy soils, it is beneficial to initially examine hydrocarbon-induced alterations in microstructure of the soils. In this regard, SEM images of both clean and contaminated Ottawa and Firoozkooh sand containing 4, 8, and 12 wt.\% of crude oil were presented in Fig. 8 and Fig. 9, respectively. As it can be observed in Fig. 8(b) and Fig. 9(b), an uniformly embedding 4 wt.\% of the hydrocarbon contaminant into the clean sand samples caused obvious alterations in both surface roughness (more obvious in Fig. 8) and particle interlocking (more obvious in Fig. 9) to some extent that some spaces between particles were covered by hydrocarbon compounds such that 
this trend might lead to a state of artificial cohesion among sand particles. Generally speaking, it seems that presence of $4 \mathrm{wt} . \%$ of crude oil contamination into sand skeleton was not influential enough to weaken surface roughness and grain interlocking of both sand types; however, the authors believe that this amount of crude oil contamination was effective in a way that it could effectively increase hydrocarbon-induced cohesion among sand particles. On the other hand, increasing the amount of oil contamination to a content higher than 4 wt.\% which can be found in Fig. 8(c and d) and Fig. 9(c and d) seems to provide an opposite effect on sand skeleton so that the space among sand grains were approximately filled by hydrocarbon compounds. Moreover, adding further oil content in sand ( $\geq 4 \mathrm{wt} . \%)$ might create a significant state of coating around each particle, and would result in a reduction in the surface roughness. More importantly, adding further oil content ( $\geq 4$ wt.\%) into sand structure could not positively affect cohesion among particles due to this fact that the used crude oil was categorized as a light type with a lower viscosity compared with heavy crude oil. In a general view, it can be inferred that the microscale changes in clean and contaminated sand structures may lead to varied macroscale shear behaviours of oil contaminated sand specimens.

Having considered the influences of light crude oil on sand structure, the present part aims at examining small-strain shear modulus of both fresh contaminated sand types using a bender element apparatus. According to the findings presented in Fig. 10, it can be inferred as a general trend in both newly contaminated sand specimens that increasing crude oil content to 4 wt. $\%$ has had a substantial effect on maximum shear modulus of sand so that $\mathrm{G}_{\max }$ of $4 \mathrm{wt} . \%$ contaminated sand was about 1.59-1.81 times more than $G_{\max }$ of clean ones at various confining pressures. By referring to the authors' observations in SEM images, this significant increment in $G_{\max }$ of contaminated sand may be associated with simultaneously positive influence of hydrocarbon 
compounds on both particle physical interlocking (friction) and cohesion (see also Fig. 8 and Fig. 9). Furthermore, the substantial negative influences have been recorded while the content of crude oil contamination rose from 4 wt. $\%$ to $8 \mathrm{wt} . \%$ in both sand types, and thereafter, adding further crude oil from $8 \mathrm{wt} . \%$ to $12 \mathrm{wt} . \%$ had a negligible impact on $\mathrm{G}_{\max }$. In this regard, based on the SEM images, it can be stated that adding further crude oil from 4 wt. $\%$ to 8 wt. $\%$ causes negative effects on $G_{\max }$ in a way that $G_{\max }$ of $8 \mathrm{wt} . \%$ contaminated sand was approximately half of that of $4 \mathrm{wt} . \%$ contaminated sand (0.46-0.52 times lower). Additionally, $\mathrm{G}_{\max }$ of 8 wt. $\%$ contaminated sand specimens was almost 0.71-0.90 times lower than those of the clean samples in different sand and confining pressures. The authors believe that adding more crude oil into sand skeleton $(\geq 4 \mathrm{wt} . \%)$ might considerably alter both surface roughness and sand particle interlocking so that a sand structure containing $8 \mathrm{wt} \%$ of hydrocarbon contamination did not have a chained skeleton in comparison to 4 wt.\% contaminated sand. In this connection, adding contaminants up to $12 \mathrm{wt} . \%$ has not also imposed perceptible changes in $\mathrm{G}_{\max }$ of sand, and the relevant curves in Fig. 10 went through a steady state. As confining pressure increased, the differences between $\mathrm{G}_{\max }$ of contaminated Ottawa and Firoozkooh sand reduced, and this trend is greatly observable at crude oil content of $4 \mathrm{wt} . \%$ so that curves of both contaminated Ottawa and Firoozkooh sand followed a similar way under a confining pressure of $500 \mathrm{kPa}$. Generally speaking, at this step, regarding short-term influences of light crude oil on $G_{\max }$ of two studied sand types, it can be said that the presence of this kind of hydrocarbon compounds up to 8 wt. $\%$ could cause obvious alterations in $G_{\max }$, and the degree of these imposed changes has been greatly sensitive to the level of confinement and moderately to the sand type. However, there was not significant changes to be reported at the highest oil content (12 wt.\%) compared with the situation at oil content of $8 \mathrm{wt} . \%$. 


\subsection{Long-term analysis}

As a key goal in the present study, this section has the aim of evaluating long-term influences of crude oil contamination on maximum shear modulus of Ottawa and Firoozkooh sand. To this end, initially, an adequate amounts of each contaminated sand containing 4, 8, and 12 wt.\% of crude oil were separated and kept in particular plastic containers outside the lab exposed to outdoor surrounding conditions including a direct exposure to sun light and also higher possibility to be contacted with wind. It is worth mentioning that, only in rarely rainy days during the weathering period, the samples were moved to a shady place outside the lab. Moreover, a thermometer was put just near the samples, and weather temperature was measured two times a day (at 12 a.m. and 12 p.m.). The containers used in the long-term analysis of the contaminated samples were supplied so that there was not any barrier to prevent light crude oil to be evaporated. In Table 3, statistical information provided by a local branch of Iran Metrological Organization along with the derived data from the authors' twice a day measurements during the period of investigation have been presented in order to clarify the imposed surrounding conditions on the samples. In this connection, it can be inferred that almost more than 48-96 percent of daytime during all 9 months of weathering process was sunny. The maximum (96\% of daytime) and minimum (48\% of daytime) number of sunny hours took place in Month \#5 (July) and Month \#8 (October), respectively. Moreover, the average temperatures recorded by the authors adjacent to the samples were higher than maximum temperatures provided by Iran Metrological Organization almost during all months with the exception of Month \#8 (October). Based on the literature [3], crude oil evaporation can happen under a wide range of temperature, and it is dependent on various physico-chemical characteristics of both crude oil and the host soil. This process is significant and influential in the case of weathering procedure of 
hydrocarbon-contaminated soil from this aspect that after evaporation of volatile hydrocarbon compounds takes place, the remained high viscose hydrocarbons into the soil skeleton may cause different effects on soil behaviour in comparison to the fresh contaminated soil. In addition, the amount of the remained hydrocarbon into soils is greatly related to soil grain size, thermal characteristics of soil and hydrocarbon as well as surrounding conditions [3, 30]. According to authors' daily measurements of sample weights during 9-month weathering procedure, the calculated percentages of hydrocarbon evaporation have been presented in Fig. 11.

At the first glance, it can be obviously seen that light crude oil evaporation was more serious in Ottawa sand than in Firoozkooh sand. Based on the relevant literature [3, 67], the observed difference may be probably associated with thermal conductivity, adhesion and/or cohesion properties of both soil and oil hydrocarbon compounds. It is also apparent that, at constant weathering conditions, crude oil evaporation diminished in contaminated soil with higher amounts of crude oil. Additionally, as the content of crude oil in the both contaminated sand increased, the amount of the remained hydrocarbon compounds also rose. The percentage of evaporation in 4 wt.\% contaminated Ottawa sand after 5 months (32.25\%) was approximately 5.23 times more than that in 12 wt.\% contaminated Ottawa sand (6.17\%), for instance. Moreover, almost in all cases, the specimens were sensitive to weathering circumstances during the first 6 months after being exposure to natural surrounding conditions, and thereafter, there were no detectable changes to be noticed. It is obvious that the majority of evaporation took place in the first 2 months, and afterwards, the procedure followed a moderate trend until month \#6.

With the intention of examining long-term influences of naturally surrounding conditions on small-strain shear modulus $\left(\mathrm{G}_{\max }\right)$ of both sand types, the authors carried out a series of BE tests 
with an emphasis and strong determination to conduct experiments under completely similar circumstances to short-term analyses after passing 2, 4, and 6 months since being exposure to natural conditions.

To evaluate the effects of weathering process on microstructures of crude oil contaminated sand, SEM images of $4 \mathrm{wt} . \%$ contaminated Ottawa sand (as the most sensitive sample to weathering procedure based on the information provided in Fig. 11) captured at specific intervals (at the end of month \#2, month \#4, and month \#6) have been presented in Fig. 12. The scale bar of $100 \mathrm{um}$ and magnification of $100 \mathrm{X}$ were chosen so as to clarify weathering-induced changes in contacts among sand particles. In this regard, it can be seen in Fig. 12 that the highest alteration was taken place during the first interval (month\#0 to month\#2) so that, in Fig. 12(a), an extensive volume of space among the particle was filled with hydrocarbon compounds, and as times passed (at the end of month\#2 (Fig. 12(b)), it can be possible to find approximately empty space between particles. To add to that, there are not considerable changes in the observable circumstances of SEM images of contaminated samples after the second month (month\#2 to month\#6). Of course, it should be emphasized here that the weathering process did not impose its changes on the samples in a homogenous and organized way, and due to this reason the previous explanation is more qualitative than quantitative.

In Fig. 13 and Fig. 14, the results of a series of BE tests conducted by the authors on aged contaminated samples of Firoozkooh and Ottawa sand have been presented, respectively. In this regard, $\mathrm{BE}$ tests were conducted under confining pressure of 100,300 , and $500 \mathrm{kPa}$ and at frequency of $15 \mathrm{kHz}$. Generally speaking, it may be anticipated at the first place as a rough guess that as weathering phenomenon develops into sand skeletons (time passes and crude oil evaporates from the specimens), the amounts of maximum shear modulus of both sands 
decrease. However, based on the actually obtained results as presented in Fig. 13 and Fig. 14, it can be obviously seen that weathering procedure could positively influence the amounts of $G_{\max }$ in both sand types. The authors believe that these findings may be related to this fact that evaporation of the volatile compounds could bring about significant changes into chemical and physical properties of the oil, and eventually this alteration may make changes in sand responses to shear wave propagation. In addition, it should be noted here that the composition of remained hydrocarbon compound is going to be much more viscous as time passes, and high-viscous light crude oil would create a more compacted sand skeleton which might be influential on $\mathrm{V}_{\mathrm{s}}$ and $\mathrm{G}_{\max }$. Moreover, the presence of a high-viscous fluid within the sand structure can form a much more chain path of shear wave into sand skeleton, thereby facilitating shear wave propagation with a higher shear wave velocity compared with fresh contaminated sand specimens. By the same token, these alterations were more perceptible in the aged 4 wt.\% contaminated specimens of both sand types; however, regarding the aged $8 \mathrm{wt} . \%$ and $12 \mathrm{wt} . \%$ contaminated samples of both sand types, the effects of weathering were not clearly detectable in comparison with aged 4 wt.\% contaminated sand. As a probable reason for this trend, it may be inferred that sand samples with a lower amount of light crude oil (4 wt.\%) have had more possibilities to be influenced by the weathering course in comparison with sand specimens with higher amounts of hydrocarbon contamination (8 and $12 \mathrm{wt} . \%)$.

With a precise look at the results provided in Fig. 13 and Fig. 14, it can be concluded that the majority of weathering-induced alterations in $G_{\max }$ was perceived during the first 2 months after the beginning of the weathering course in both sand types. Furthermore, from month \#4 to month \#6, there were not serious changes made by the weathering stages, and the tendency of imposed changes was on a slightly moderate path so that the curves of month \#2, month \#4, and month \#6 
were approximately placed much closer together compared with the difference between curve of month \#0 and month \#2. As a well-known trend in long-term analysis [30], the degree of weathering-imposed changes has been always diminished slightly as times passes during the weathering course (provided the surrounding circumstances do not dramatically alter); however, the degree of changes are usually more impressive within the first part of weathering period. Moreover, the gap between curve of month \#0 and month \#2 is more distinguishable in Ottawa sand than in Firoozkooh sand. By the same token, these observations might be associated with the previous recorded measurements of crude oil evaporation showing that the higher escape of volatile compounds from crude oil contaminated sand was more detectable in Ottawa sand when compared with Firoozkooh sand. Consequently, it could lead to a greater increment in the amount of $G_{\max }$ in this sand type.

In a general view, it can be said that the changes imposed on $G_{\max }$ during the weathering steps were more straightforward in all aged 4 wt.\% contaminated sand as sequential steps in which $\mathrm{G}_{\max }$ of aged 4 wt. $\%$ contaminated sand gradually increased with different rates as time passed (pointed by red arrows in Fig. 13 and Fig. 14). However, trend of changes were more complex in the case of both aged $8 \mathrm{wt} . \%$ and $12 \mathrm{wt} . \%$ contaminated sand. To add to that, it was also seen in the results that as confining pressure rises, $\mathrm{G}_{\max }$ of both aged $8 \mathrm{wt} . \%$ and $12 \mathrm{wt} . \%$ contaminated sand closes together especially after the second month (month \#2), but this observation was not a case in both 4 wt.\% contaminated sand types, and surprisingly, in a higher level of confinement, the weathering influences on $G_{\max }$ of $4 \mathrm{wt} . \%$ contaminated sand types were more perceivable. The authors believe that, in the case of both aged $8 \mathrm{wt} . \%$ and $12 \mathrm{wt} . \%$ contaminated sand, there were not obviously weathering-induced changes on the structure of both sand types, and accordingly detectable changes could not be recorded in $\mathrm{G}_{\max }$ by testing procedure, but 4 wt. $\%$ 
contaminated sand samples, as previously explained, were more sensitive to the weathering, and the clearly observed alterations could be reasonable. Finally, it should be noted here that since the influences of the weathering was not significant to be reported after the month \#6, the analytical procedure of long-term evaluation of contaminated sand samples was specific to the first 6 months.

\section{Conclusion}

The present research tried to experimentally evaluate both short- and long-term influences of a type of light crude oil contamination on $G_{\max }$ of Ottawa and Firoozkooh sand. To this aim, a series of BE tests was conducted on similarly prepared clean and fresh/aged contaminated samples under various frequencies $(2-20 \mathrm{kHz})$ and confining pressures $(100-500 \mathrm{kPa})$. As an overall analysis, the findings of this study have been briefly presented as follows:

1. Peak-to-peak, start-to-start, and cross-correlation methods could detect the most reliable shear wave arrival time in the BE tests.

2. There was a critical amount of light crude oil contaminant (here $4 \mathrm{wt} . \%$ ) in the short-term analyses at which the value of $G_{\text {max }}$ reached its peak so that adding crude oil into clean sand up to this particular content gradually increased $\mathrm{G}_{\max }$, and beyond this criterion, any further presence of contaminant into sand skeleton brought about decreasing effects on $\mathrm{G}_{\text {max }}$. It seems that this critical value is depended on both soil and contaminant characteristics.

3. The weathering-induced influences on $G_{\max }$ gradually alleviated as time passed, and the degree of imposed changes was remarkable during the first two months. In addition, weathering process was more influential on $G_{\max }$ of Ottawa sand, probably as a result of 
existing differences among thermal conductivity, adhesion and/or cohesion properties of both sand and hydrocarbon.

4. The weathering effects on $\mathrm{G}_{\max }$ were more severe in those samples containing the critical hydrocarbon content (here 4 wt.\%), and samples with higher amounts of contamination responded to the weathering negligibly.

\section{Acknowledgment}

The authors would finally like to profoundly appreciate the valuable supports in conducting this study provided by West Oil and Gas Production Company (WOGPC) of Iran, Soil Mechanics Industry of Iran (SMI), Iranian Metrological Organization (Kermanshah Branch), and also International Institute of Earthquake Engineering and Seismology of Iran (IIEES).

\section{References}

[1] I.A. Mirsal, Soil Pollution Origin, Monitoring \& Remediation, Springer, Germany, 2004.

[2] H.A. Al-Sanad, W.K. Eid, N.F. Ismael, Geotechnical Properties of Oil-Contaminated Kuwaiti Sand, Journal of Geotechnical Engineering, 121 (1995) 407-412.

[3] M. Khamehchiyan, A. Hossein Charkhabi, M. Tajik, Effects of crude oil contamination on geotechnical properties of clayey and sandy soils, Engineering Geology, 89 (2007) 220-229.

[4] Z.A. Rahman, U. Hamzah, N. Ahmad, Geotechnical Characteristics of Oil-Contaminated Granitic and Metasedimentary Soils, Asian Journal of Applied Sciences, 3 (2010) 237-249. [5] S.A. Naeini, M.M. Shojaedin, Effect of oil contamination on the liquefaction behavior of sandy soils, International Journal of Environmental, Chemical, Ecological, Geological and Geophysical Engineering, 8 (2014) 289-292. 
[6] S.A. Aiban, The Long-term Environmental Effects of the Gulf WarThe effect of temperature on the engineering properties of oil-contaminated sands, Environment International, 24 (1998) $153-161$.

[7] E.E. Cook, V.K. Puri, E.C. Shin, Geotechnical Characteristics Of Crude Oil-Contaminated Sands, in: The Second International Offshore and Polar Engineering Conference, International Society of Offshore and Polar Engineers, San Francisco, California, USA, 1992.

[8] M. Kermani, T. Ebadi, The Effect of Oil Contamination on the Geotechnical Properties of Fine-Grained Soils, Soil and Sediment Contamination: An International Journal, 21 (2012) 655671.

[9] V.K. Puri, B.M. Das, E.E. Cook, E.C. Shin, Geotechnical Properties of Crude Oil Contaminated Sand, in: Special Technical Publication (STP) 1221, ASTM, 1994.

[10] E.C. Shin, J.B. Lee, B.M. Das, Bearing Capacity of a Model Scale Footing on Crude OilContaminated Sand, Geotechnical \& Geological Engineering, 17 (1999) 123-132.

[11] S.K. Singh, R.K. Srivastava, S. John, Studies on soil contamination due to used motor oil and its remediation, Canadian Geotechnical Journal, 46 (2009) 1077-1083.

[12] R.K. Srivastava, V.D. Pandey, Geotechnical evaluation of oil contaminated soil, in: R.W. Sarsby (Ed.) the proceeding of CREEN 2 in the second international symposium on Geotechnics Related to the Environment Thomas Telford, London, Krakow, Poland, 1997.

[13] A. Tuncan, S. Pamukcu, Geotechnical Properties of petroleum and sludge contaminatd marine sediments, in: the Second (1992) International Offshore and Polar Engineering Conference, The International Society of Offshore and Polar Engineers, San Francisco, USA,, 1992, pp. 14-19. 
[14] E.C. Shin, B.M. Das, Bearing Capacity of Unsaturated Oil-Contaminated Sand, International Journal of Offshore and Polar Engineering, 11 (2001) 220-226.

[15] S.K. Singh, R.K. Srivastava, S. John, Settlement Characteristics of Clayey Soils Contaminated with Petroleum Hydrocarbons, Soil and Sediment Contamination: An International Journal, 17 (2008) 290-300.

[16] A.J.L.M. Siang, D.C. Wijeyesekera, S.M.A.S. Yahya, M. Ramlan, Innovative testing investigations on the influence of particle morphology and oil contamination on the geotechnical properties of sand, International Journal of Integrated Engineering, 6 (2014) 60-66.

[17] I.I. Akinwumi, U.R. Maiyaki, S.A. Adubi, S.O. Daramola, B.B. Ekanem, Effects of waste engine oil contamination on the plasticity, strength and permeability of lateritic clay, International Journal of Scientific \& Technology Reseaech, 3 (2014) 331-335.

[18] E.C. Shin, M.T. Omar, A.A. Tahmaz, B.M. Das, Shear strength and hydraulic conductivity of oil-contaminated sand, in: M.A. L.G. de Mello (Ed.) Proceedings of the Fourth International Congress on Environmental Geotechnics,, A.A. Balkema Publishers, Lisse,, Rio de Janeiro, Brazil, 2002, pp. 9-13.

[19] B.S. Walia, G. Singh, M. Kaur, Study of diesel contaminated clayey soil, in: Proceedings of Indian Geotechnical Conference, Springer, Roorkee, India, 2013.

[20] S.S. Pusadkar, P.S. Bharambe, Performance of petrol and diesel contaminated black cotton soil, International Journal of Engineering Research \& Technology (IJERT), 3 (2014) 536-539. [21] G. Solly, E.A. Aswathy, S. Berlin, N.P. Krishnaprabha, G. Maria, Study of geotechnical properties of diesel oil contaminated soil, International Journal of Civil and Structural Engineering Research, 2 (2015) 113-117. 
[22] L. Di Matteo, F. Bigotti, R. Ricco, Compressibility of Kaolinitic Clay Contaminated by

Ethanol-Gasoline Blends, Journal of Geotechnical and Geoenvironmental Engineering, 137

(2011) 846-849.

[23] S.Y. Ling, L.C. Yong, Behavior of piles in palm biodiesel contaminated mining sand, International journal of environmental science 3(2013) 1822-1830.

[24] E. Evgin, B.M. Das, Mechanical behavior of an oil contaminated sand, in: U.a. Acar. (Ed.) Envir. Geotechnol., Proc., Mediterranean Conf., Balkema Publishers, Rotterdam. The Netherlands, 1992, pp. 101-108.

[25] V. Silvestri, N. Mikhail, M. Souli, Permeability Response of Oil-Contaminated Compacted Clays, ASTM International STP1275 (1997) 62-74.

[26] A.K. Nazir, Effect of motor oil contamination on geotechnical properties of over consolidated clay, Alexandria Engineering Journal, 50 (2011) 331-335.

[27] A.M.A. Nasr, Uplift Behavior of Vertical Piles Embedded in Oil-Contaminated Sand, Journal of Geotechnical and Geoenvironmental Engineering, 139 (2013) 162-174.

[28] T.S. Ijimdiya, The Effects of Oil Contamination on the Consolidation Properties of Lateritic Soil, Development and Applications of Oceanic Engineering (DAOE), 2 (2013) 53-59.

[29] S.A. Ola, Geotechnical properties and behaviour of Nigerian tar sand, Engineering Geology, 30 (1991) 325-336.

[30] H.A. Al-Sanad, N.F. Ismael, Aging Effects on Oil-Contaminated Kuwaiti Sand, Journal of Geotechnical and Geoenvironmental Engineering, 123 (1997) 290-293.

[31] E. Khosravi, H. Ghasemzadeh, M.R. Sabour, H. Yazdani, Geotechnical properties of gas oil-contaminated kaolinite, Engineering Geology, 166 (2013) 11-16. 
[32] H.M. Alhassan, S.A. Fagge, Effects of crude Oil, low point pour fuel oil and vacuum gas oil contamination on the geotechnical properties sand, clay and laterite soils, International Journal of Engineering Research and Applications, 3 (2013) 1947-1954.

[33] I.I. Akinwumi, D. Diwa, N. Obianigwe, Effects of crude oil contamination on the index properties, strength and permeability of lateritic clay, Internationla Journal of Applied Sciences and Engineering Research, 3 (2014) 816-824.

[34] Y.G. Jia, Q. Wu, X. Meng, X. Yang, Z. Yang, G. Zhang, Case Study on Influences of Oil Contamination on Geotechnical Properties of Coastal Sediments in The Yellow River Delta, in: Y. Chen, L. Zhan, X. Tang (Eds.) Advances in Environmental Geotechnics: Proceedings of the International Symposium on Geoenvironmental Engineering in Hangzhou, China, September 810, 2009, Springer Berlin Heidelberg, Berlin, Heidelberg, 2010, pp. 767-771.

[35] D.K. Talukdar, B.D. Saikia, Effect of crude oil on some consolidation properties of clayey soil, International Journal of Emerging Technology and Advanced Engineering, 3 (2013) 117120.

[36] E.C. Ukpong, I.C. Umoh, Effects of ccrude oil spillage on geotecchnical propertiess of lateritic soil in Okoroete, eastern Obololo, International Journal of Engineering and Applied Sciences, 7 (2015) 12-24.

[37] M. Budhu, R.F. Giese Jr, G. Campbell, L. Baumgrass, The permeability of soils with organic fluids, Canadian Geotechnical Journal, 28 (1991) 140-147.

[38] D.E. Foreman, D.E. Daniel, Permeation of Compacted Clay with Organic Chemicals, Journal of Geotechnical Engineering, 112 (1986) 669-681.

[39] J. Meegoda, R.A. Rajapakse, Short-Term and Long-Term Permeabilities of Contaminated Clays, Journal of Environmental Engineering, 119 (1993) 725-743. 
[40] Z.A. Rahman, U. Hamzah, M.R. Taha, N.S. Ithnain, N. Ahmad, Influence of Oil Contamination on Geotechnical Properties of Basaltic Residual Soil, American Journal of Applied Sciences, 7 (2010) 8.

[41] J.O. Uppot, R.W. Stephenson, Permeability of Clays Under Organic Permeants, Journal of Geotechnical Engineering, 115 (1989) 115-131.

[42] J. Ochepo, V. Joseph, Effect of oil contamination on lime stabilized soil, Jordan Journal of Civil Engineering, 8 (2014) 88-96.

[43] O.B. Oyegbile, G.M. Ayininuola, Laboratory Studies on the Influence of Crude Oil Spillage on Lateritic SoilShear Strength: A Case Study of Niger Delta Area of Nigeria, Journal of Earth Sciences and Geotechnical Engineering, 3 (2013) 73-83.

[44] K.C. Onyelowe, Pure crude oil contamination on Amaoba lateritic soil, The Electronic Journal of Geotechnical Engineering (EJGE), 20 (2015) 1129-1142.

[45] H. Rahman, S.N. Abduljauwad, S.N. Akram, Geotechnical Behavior of Oil-Contaminated Fine-Grained Soils, Electronic Journal of Geotechnical Engineering, 12 (2007).

[46] V.K. Puri, Geotechnical Aspects of Oil-Contaminated Sands, Journal of Soil Contamination, 9 (2000) 359-374.

[47] A.R. Estabragh, I. Beytolahpour, M. Moradi, A.A. Javadi, Mechanical behavior of a clay soil contaminated with glycerol and ethanol, European Journal of Environmental and Civil Engineering, 20 (2016) 503-519.

[48] J. Meegoda, P. Ratnaweera, Compressibility of contaminated fine-grained soils, Geotechnical Testing Journal, 17 (1994) 101-112. 
[49] R. Dyvik, C. Madshus, Lab Measurements of Gmax Using Bender Element, in: Proc.

ASCE convention on Advances in the art of testing soils under cyclic conditions, 1986, pp. 186196.

[50] G. Viggiani, J.H. Atkinson, Interpretation of bender element tests, Géotechnique, 45 (1995) $149-154$.

[51] J.-S. Lee, J.C. Santamarina, Bender Elements: Performance and Signal Interpretation, Journal of Geotechnical and Geoenvironmental Engineering, 131 (2005) 1063-1070.

[52] S. Yamashita, T. Kawaguchi, Y. Nakata, T. Mikami, T. Fujiwara, S. Shibuya, INTERPRETATION OF INTERNATIONAL PARALLEL TEST ON THE MEASUREMENT OF $<\mathrm{i}>\mathrm{G}</ \mathrm{i}><\mathrm{sub}>\max </$ sub $>$ USING BENDER ELEMENTS, SOILS AND FOUNDATIONS, 49 (2009) 631-650.

[53] X. Gu, J. Yang, M. Huang, Laboratory measurements of small strain properties of dry sands by bender element, Soils and Foundations, 53 (2013) 735-745.

[54] Y. Cai, Q. Dong, J. Wang, C. Gu, C. Xu, Measurement of small strain shear modulus of clean and natural sands in saturated condition using bender element test, Soil Dynamics and Earthquake Engineering, 76 (2015) 100-110.

[55] J. Kumar, B.N. Madhusudhan, A note on the measurement of travel times using bender and extender elements, Soil Dynamics and Earthquake Engineering, 30 (2010) 630-634.

[56] ASTM, Standard Specification for Standard Sand, in, ASTM International,, West Conshohocken, PA, 2013, 2009, pp. 1-3.

[57] R. Ladd, Preparing Test Specimens Using Undercompaction, Geotechnical Testing Journal, 1 (1978) 16-23. 
[58] M. Raghunandan, A. Juneja, B. Hsiung, Preparation of reconstituted sand samples in the laboratory, International Journal of Geotechnical Engineering, 6 (2012) 125-131.

[59] C. Murillo, M. Sharifipour, B. Caicedo, L.U.C. Thorel, C. Dano, ELASTIC PARAMETERS OF INTERMEDIATE SOILS BASED ON BENDER-EXTENDER ELEMENTS PULSE TESTS, SOILS AND FOUNDATIONS, 51 (2011) 637-649.

[60] V. Jovičić, M.R. Coop, M. Simić, Objective criteria for determining Gmax from bender element tests, Géotechnique, 46 (1996) 357-362.

[61] E. Brignoli, M. Gotti, K. Stokoe, Measurement of Shear Waves in Laboratory Specimens by Means of Piezoelectric Transducers, (1996).

[62] D.C.F.L. Presti, M. Jamiolkowski, O. Pallara, A. Cavallaro, S. Pedroni, Shear modulus and damping of soils, Géotechnique, 47 (1997) 603-617.

[63] I. Sanchez-Salinero, Analytical investigation of seismic methods used for engineering application, in, The University of Texas at Austin, Austin, Texas, 1987.

[64] M. Arroyo, D.M. Wood, P.D. Greening, L. Medina, J. Rio, Effects of sample size on bender-based axial G0 measurements, Géotechnique, 56 (2006) 39-52.

[65] E.C. Leong, J. Cahyadi, H. Rahardjo, Measuring shear and compression wave velocities of soil using bender-extender elements, Canadian Geotechnical Journal, 46 (2009) 792-812.

[66] C. Mancuso, A.L. Simonelli, F. Vinale, Numerical analysis of in situ S-wave measurements, in: Proc 12th International Conference on Soil Mechanics and. Foundation Engineering, 13-18 August 1989, Rio de Janeiro, 1989, pp. 2891-2893.

[67] D. Łydżba, M. Rajczakowska, A. Różański, D. Stefaniuk, Influence of the Moisture Content and Temperature on the Thermal Properties of Soils: Laboratory Investigation and Theoretical Analysis, Procedia Engineering, 91 (2014) 298-303. 


\section{List of Tables}

Table 1. Basic properties of the used Ottawa sand and Firoozkooh sand along with standard Ottawa sand [56]

Table 2. Specifications of the prepared samples for both short- and long-term analyses

Table 3. Weather statistical parameters during the considered period of time for weathering analysis

\section{List of Figures}

Fig. 1. PSD curves of the used Ottawa and Firoozkooh sand along with standard Ottawa sand described by [56]

Fig. 2. (a) Digitally controlled triaxial apparatus (STRASSENTEST OHG, Germany) equipped with an additional passive triaxial cell (SMI) (b) bender elements (SMI)

Fig. 3. (a) A schematic drawing of the prepared sample in the triaxial test cell equipped with BEs along with graphical illustration of Near-Field-Effect phenomenon as well as images of two prepared cylindrical samples of sand in (b) clean and (c) 12 wt.\% hydrocarboncontaminated circumstance

Fig. 4. Primary BE results on clean oven-dried Ottawa sand under $\sigma_{3}=300 \mathrm{kPa}$ and $\mathrm{e}_{0}=0.715$ at various amounts of excitation frequencies

Fig. 5. Primary BE results on clean oven-dried Firoozkooh sand under $\sigma_{3}=300 \mathrm{kPa}$ and $\mathrm{e}_{0}=$ 0.715 at various amounts of excitation frequencies

Fig. 6. Normalized signals of typical shear transmitted wave and the received one along with the resultant cross-correlation curve 
Fig. 7. Shear wave arrival time (ms) measured by start-to-start, peak-to-peak, cross-correlation and resonant column test for oven-dried (a) Ottawa and (b) Firoozkooh sand $\left(\mathrm{e}_{0}=0.715\right)$

Fig. 8. SEM images of (a) clean oven-dried, (b) 4 wt.\% crude oil contaminated, (c) 8 wt.\% crude oil contaminated, and (d) 12 wt.\% crude oil contaminated Ottawa sand captured at 26000 Volt with scale bar of $10 \mathrm{um}$ and magnification of $1.00 \mathrm{KX}$

Fig. 9. SEM images of (a) clean oven-dried, (b) 4 wt. $\%$ crude oil contaminated, (c) 8 wt. $\%$ crude oil contaminated, and (d) 12 wt.\% crude oil contaminated Firoozkooh sand captured at 26000 Volt with scale bar of $10 \mathrm{um}$ and magnification of $1.00 \mathrm{KX}$

Fig. 10. Maximum shear modulus $(\mathrm{MPa})$ of clean and contaminated Ottawa and Firoozkooh sand with various crude oil contents $\left(4,8\right.$, and 12 wt.\%) and $\mathrm{e}_{0}=0.715$ at frequency of 15 $\mathrm{kHz}$

Fig. 11. The remained crude oil (wt.\%) in both types of contaminated sand with (a) 4 wt.\%, (b) 8 wt.\%, (c) 12 wt.\% of light crude oil

Fig. 12. SEM images of 4 wt.\% crude oil contaminated Ottawa sand in the status of (a) fresh (month \#0), (b) 2 months after contamination (month \#2), (c) 4 months after contamination (month \#4), and (d) 6 months after contamination (month \#6) captured at 26000 Volt with scale bar of 100 um and magnification of $100 \mathrm{X}$

Fig. 13. $G_{\max }$ of aged contaminated Firoozkooh sand under various confining pressures of (a) $100 \mathrm{kPa}$, (B) $300 \mathrm{kPa}$, and (C) $500 \mathrm{kPa}$

Fig. 14. $G_{\max }$ of aged contaminated Ottawa sand under various confining pressures of (a) 100 $\mathrm{kPa}$, (B) $300 \mathrm{kPa}$, and (C) $500 \mathrm{kPa}$ 


\section{Tables}

Table 1. Basic properties of the used Ottawa and Firoozkooh sand along with standard Ottawa sand [56]

\begin{tabular}{|l|c|c|c|c|c|c|}
\hline \multicolumn{1}{|c|}{ Sand type } & $\mathbf{G}_{\mathbf{s}}$ & $\mathbf{D}_{\mathbf{1 0}}$ & $\mathbf{D}_{\mathbf{3 0}}$ & $\mathbf{D}_{\mathbf{6 0}}$ & $\mathbf{C}_{\mathbf{u}}$ & $\mathbf{C}_{\mathbf{c}}$ \\
\hline Standard Ottawa [56] - upper limit & 2.65 & 0.234 & 0.314 & 0.397 & 1.696 & 1.059 \\
\hline The used Ottawa sand & 2.65 & 0.221 & 0.307 & 0.390 & 1.763 & 1.090 \\
\hline Standard Ottawa [56] - lower limit & 2.65 & 0.217 & 0.300 & 0.383 & 1.769 & 1.084 \\
\hline Firoozkooh sand & 2.63 & 0.158 & 0.202 & 0.297 & 1.878 & 0.866 \\
\hline
\end{tabular}

Table 2. Specifications of the prepared samples for both short- and long-term analyses

\begin{tabular}{|c|c|c|c|c|}
\hline Test type & Sand type & $\begin{array}{l}\text { Sample } \\
\text { condition }\end{array}$ & $\begin{array}{c}\text { Oil } \\
\text { content } \\
\text { (wt. } \% \text { ) }\end{array}$ & $\begin{array}{c}\text { Void ratio } \\
\left(\mathrm{e}_{0} \cong 0.715\right)\end{array}$ \\
\hline \multirow{8}{*}{ Short-term analyses } & \multirow{4}{*}{ Ottawa Sand } & Clean & 0 & 0.71593 \\
\hline & & Contaminated & 4 & 0.71625 \\
\hline & & Contaminated & 8 & 0.71521 \\
\hline & & Contaminated & 12 & 0.71465 \\
\hline & \multirow{4}{*}{$\begin{array}{l}\text { Firoozkooh } \\
\text { Sand }\end{array}$} & Clean & 0 & 0.71494 \\
\hline & & Contaminated & 4 & 0.71568 \\
\hline & & Contaminated & 8 & 0.71476 \\
\hline & & Contaminated & 12 & 0.71556 \\
\hline \multirow{6}{*}{$\begin{array}{l}\text { Long-term analyses } \\
\text { (weathering)* }\end{array}$} & \multirow{3}{*}{ Ottawa Sand } & Contaminated & 4 & 0.71474 \\
\hline & & Contaminated & 8 & 0.71591 \\
\hline & & Contaminated & 12 & 0.71470 \\
\hline & \multirow{3}{*}{$\begin{array}{l}\text { Firoozkooh } \\
\text { Sand }\end{array}$} & Contaminated & 4 & 0.71461 \\
\hline & & Contaminated & 8 & 0.71437 \\
\hline & & Contaminated & 12 & 0.71443 \\
\hline
\end{tabular}

* The specifications of both 6-month contaminated sands were provided as an illustrative example of aged specimens. 
Table 3. Weather statistical parameters during the considered period of time for weathering analysis measured

\begin{tabular}{|c|c|c|c|c|c|c|c|c|c|}
\hline \multirow{2}{*}{$\begin{array}{c}\text { Weather statistical } \\
\text { parameters }\end{array}$} & \multicolumn{9}{|c|}{ Weathering period } \\
\hline & $\begin{array}{l}\text { March } \\
\text { (Month } \\
\# 1)\end{array}$ & $\begin{array}{l}\text { April } \\
\text { (Month } \\
\# 2)\end{array}$ & $\begin{array}{l}\text { May } \\
\text { (Month } \\
\text { \#3) }\end{array}$ & $\begin{array}{l}\text { June } \\
\text { (Month } \\
\text { \#4) }\end{array}$ & $\begin{array}{l}\text { July } \\
\text { (Month } \\
\# 5)\end{array}$ & $\begin{array}{l}\text { August } \\
\text { (Month } \\
\# 6 \text { ) }\end{array}$ & $\begin{array}{l}\text { September } \\
\text { (Month } \\
\# 7 \text { ) }\end{array}$ & $\begin{array}{l}\text { October } \\
\text { (Month } \\
\# 8)\end{array}$ & $\begin{array}{l}\text { November } \\
\text { (Month } \\
\# 9)\end{array}$ \\
\hline $\begin{array}{l}\text { Maximum temperature } \\
\left({ }^{\circ} \mathrm{C}\right)^{*}\end{array}$ & 28.6 & 33.5 & 39 & 42.5 & 41.3 & 37.7 & 34.6 & 27.5 & 17.3 \\
\hline Average temperature $\left({ }^{\circ} \mathrm{C}\right)^{*}$ & 12.3 & 19.3 & 26 & 29.8 & 30.6 & 25.8 & 20.1 & 11 & 4.7 \\
\hline $\begin{array}{l}\text { Average recorded } \\
\text { temperature outside the lab } \\
\left({ }^{\circ} \mathrm{C}\right)^{* *}\end{array}$ & 30.5 & 35.5 & 41.5 & 43.0 & 40.5 & 37.0 & 35.5 & 25.5 & 20.5 \\
\hline Sunny days (hours) * & 255 & 297 & 332 & 311.9 & 355.9 & 296 & 235.9 & 169.3 & 181.1 \\
\hline $\begin{array}{l}\text { Maximum absolute } \\
\text { humidity }\left(\mathrm{gr} / \mathrm{m}^{3}\right)^{*}\end{array}$ & 51 & 30 & 17 & 15 & 13 & 21 & 27 & 66 & 65 \\
\hline $\begin{array}{l}\text { Average absolute humidity } \\
\left(\mathrm{gr} / \mathrm{m}^{3}\right)^{*}\end{array}$ & 26 & 8 & 5 & 5 & 4 & 7 & 12 & 40 & 42 \\
\hline
\end{tabular}

* Data provided by the local branch of Iran Metrological Organization

** Based on the authors' twice-a-day measurements (at 12 a.m. and 12 p.m.) 


\section{Figures}

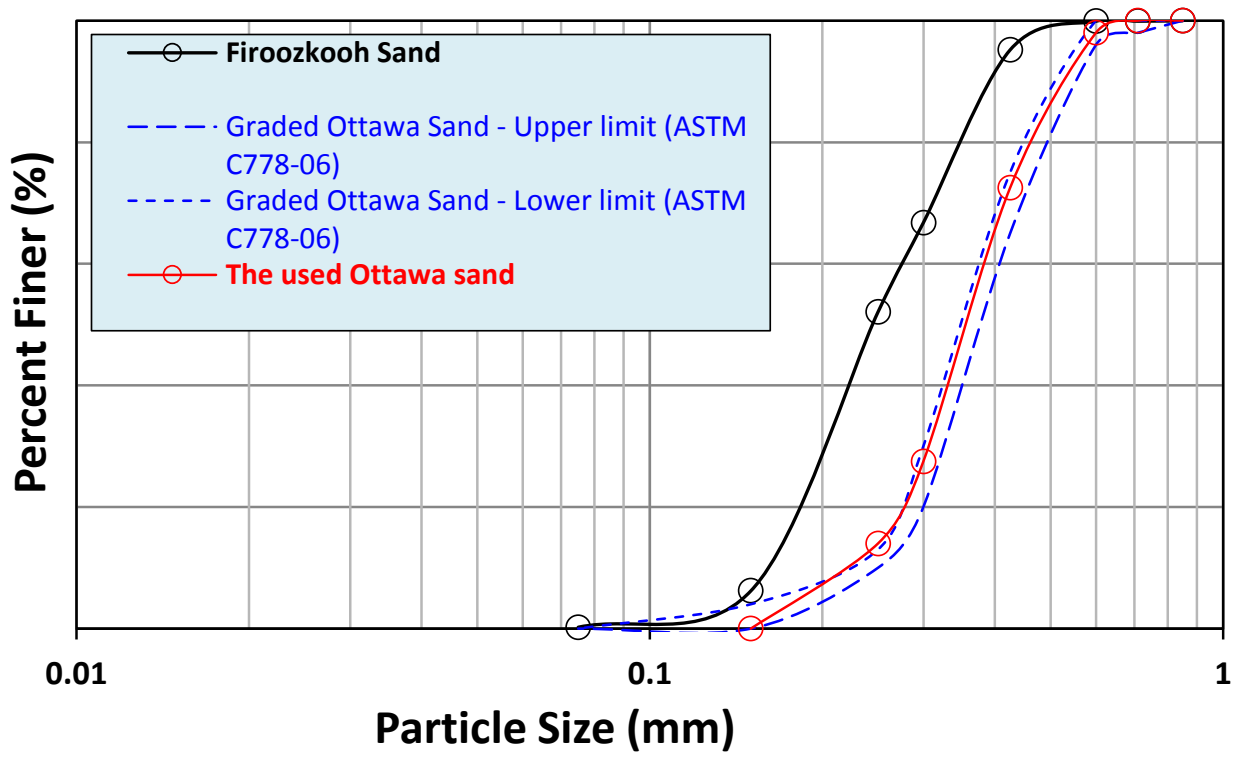

Fig. 1. PSD curves of the used Ottawa, Firoozkooh sand and the standard Ottawa sand described by [56] 

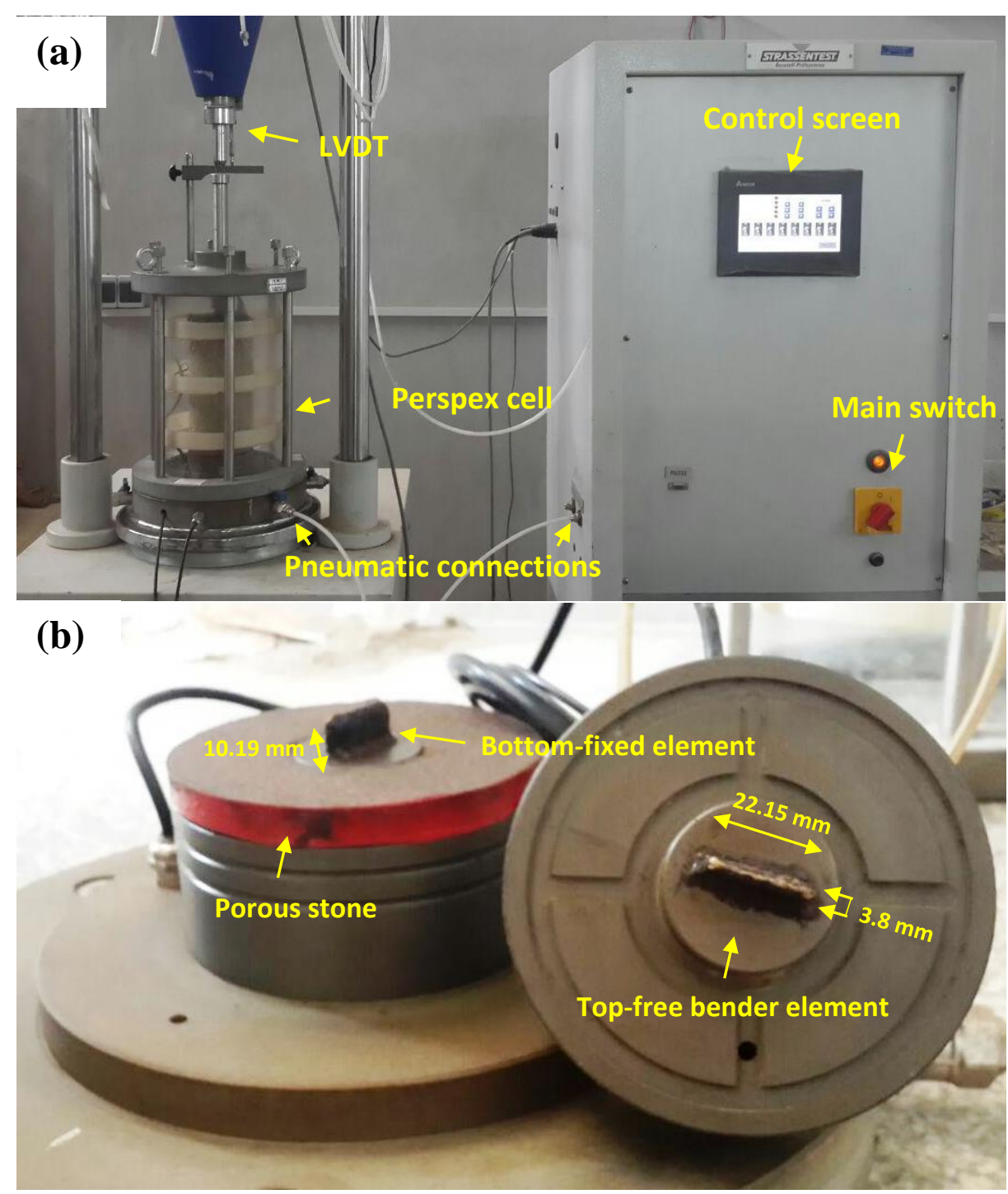

Fig. 2. (a) Digitally controlled triaxial apparatus (STRASSENTEST OHG, Germany) equipped with an additional passive triaxial cell (SMI) (b) bender elements (SMI) 

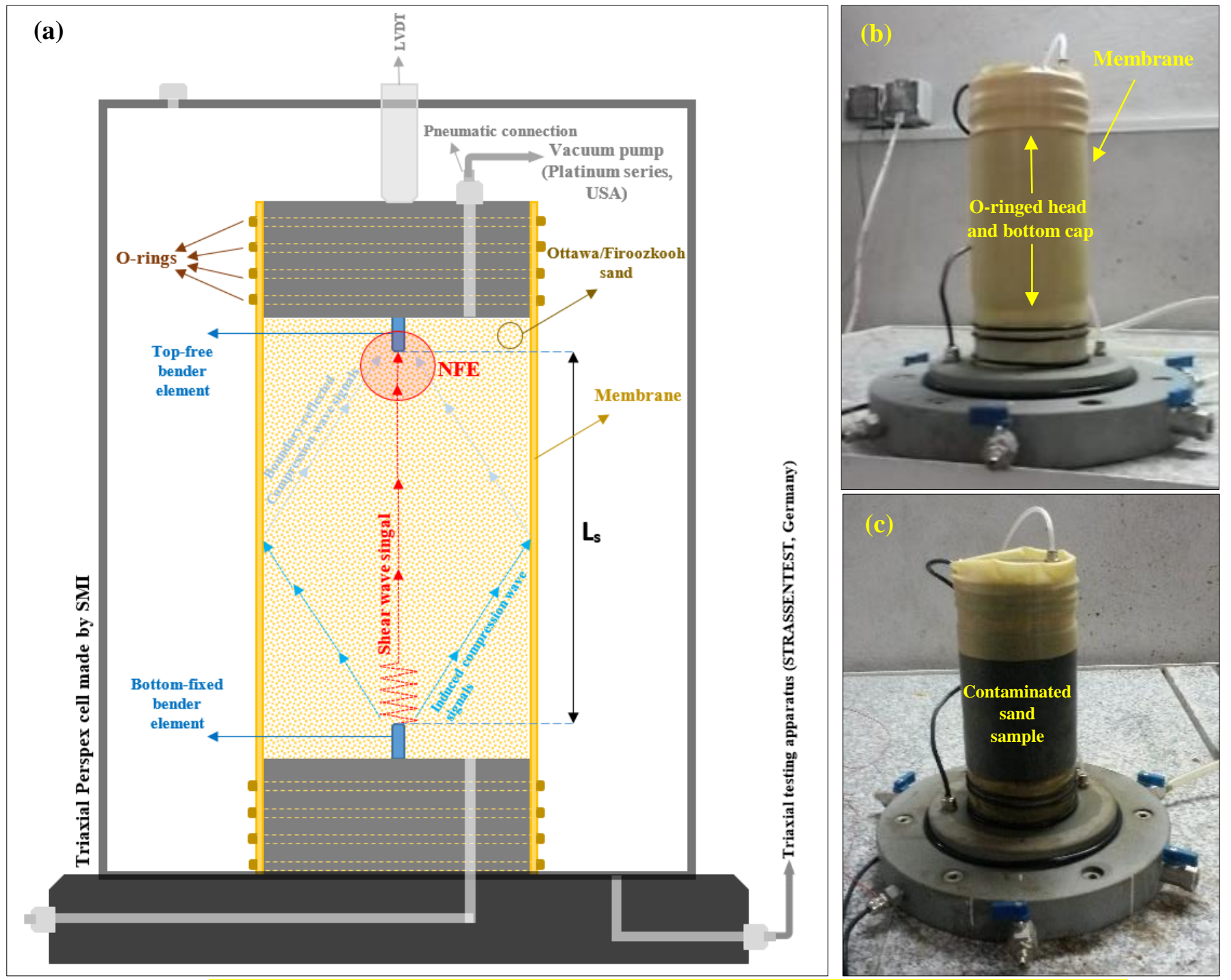

Fig. 3. (a) A schematic drawing of the prepared sample in the triaxial testing cell equipped with BEs along with a graphical illustration of Near-Field-Effect phenomenon as well as images of two prepared cylindrical samples of sand in (b) clean and (c) $12 \mathrm{wt} . \%$ hydrocarboncontaminated circumstance 


\section{Clean Ottawa sand}

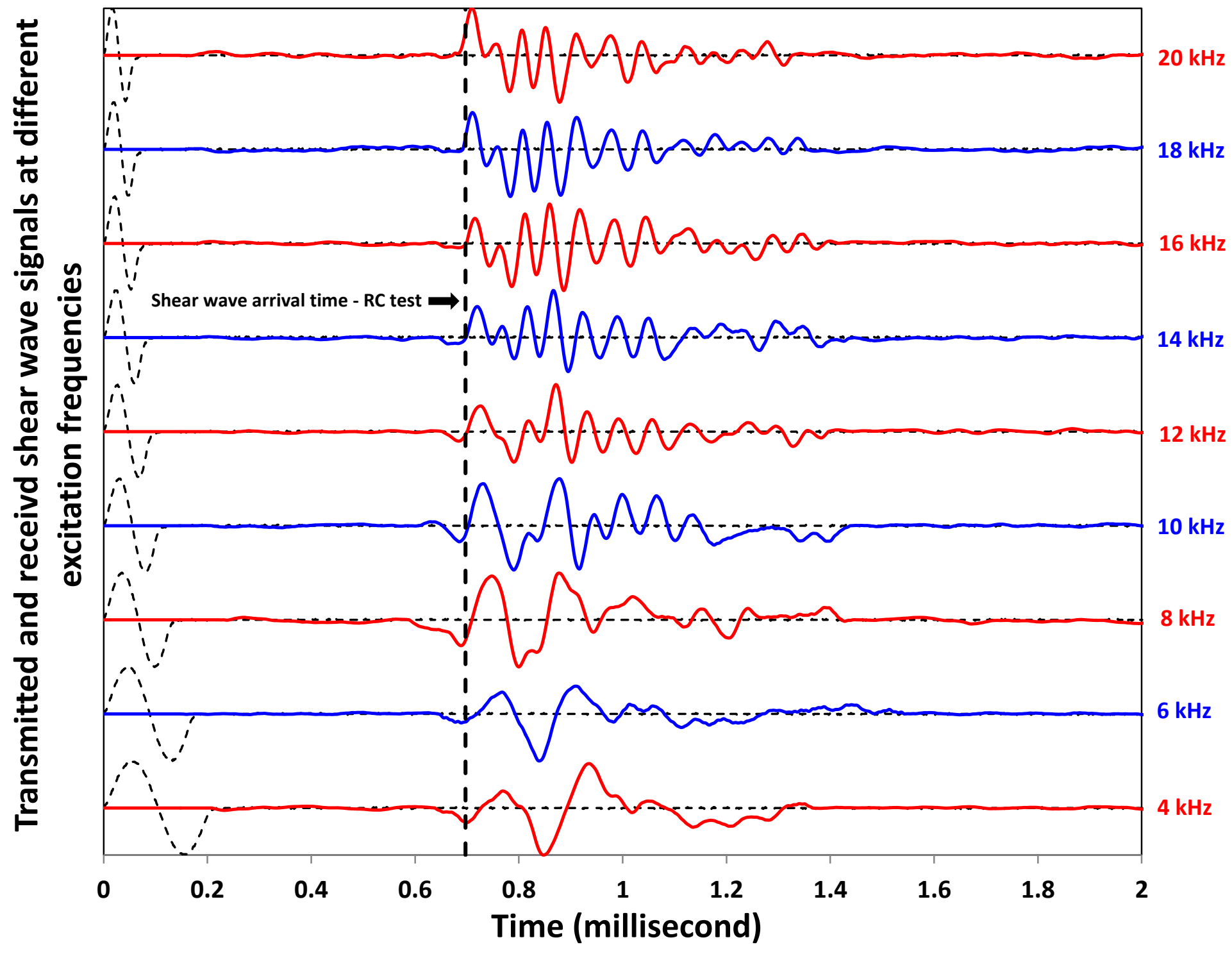

Fig. 4. Primary BE results on clean oven-dried Ottawa sand under $\sigma_{3}=300 \mathrm{kPa}$ and $\mathrm{e}_{0}=0.715$ at various amounts of excitation frequencies 


\section{Clean Firoozkooh sand}

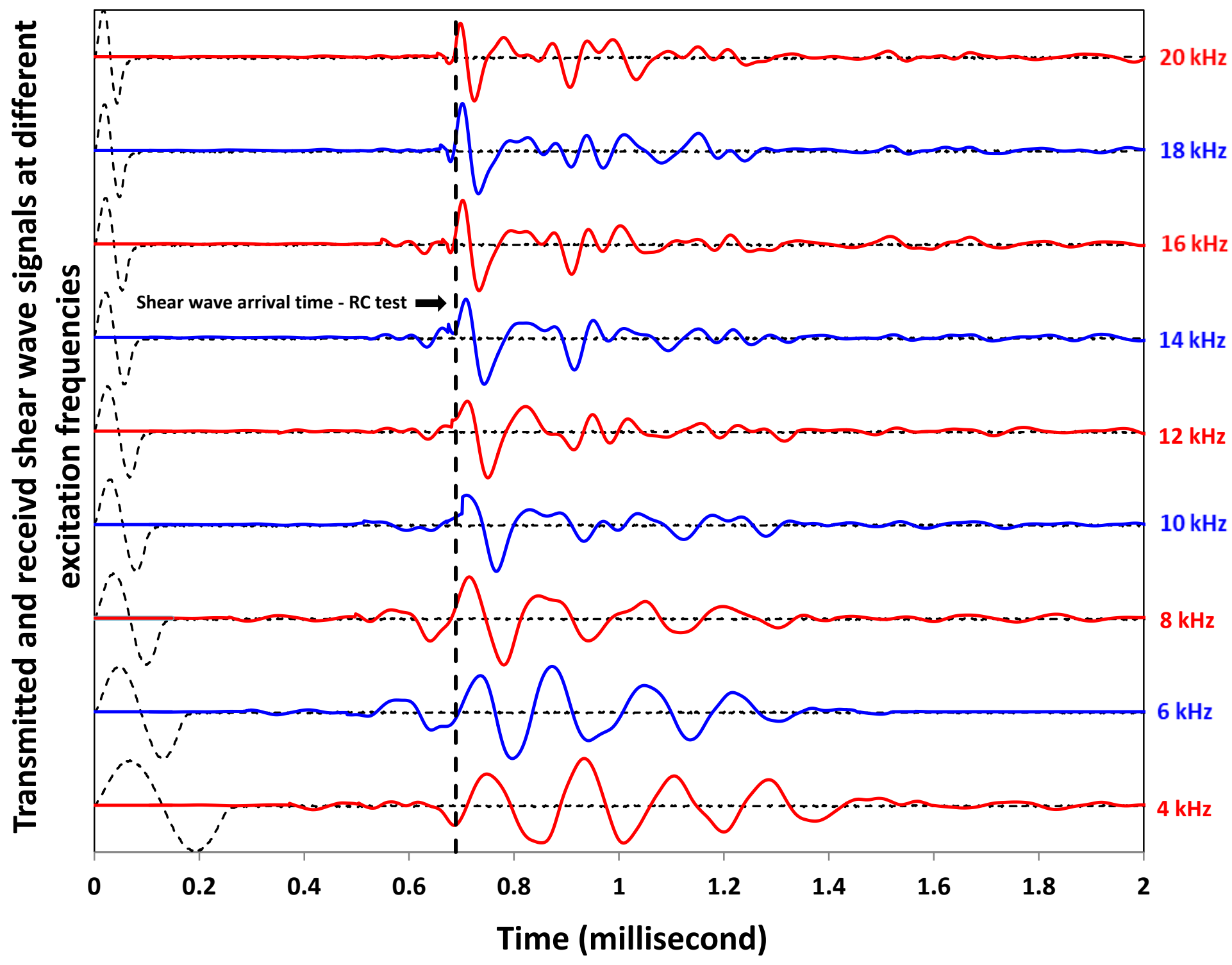

Fig. 5. Primary BE results on clean oven-dried Firoozkooh sand under $\sigma_{3}=300 \mathrm{kPa}$ and $\mathrm{e}_{0}=0.715$ at various amounts of excitation frequencies 


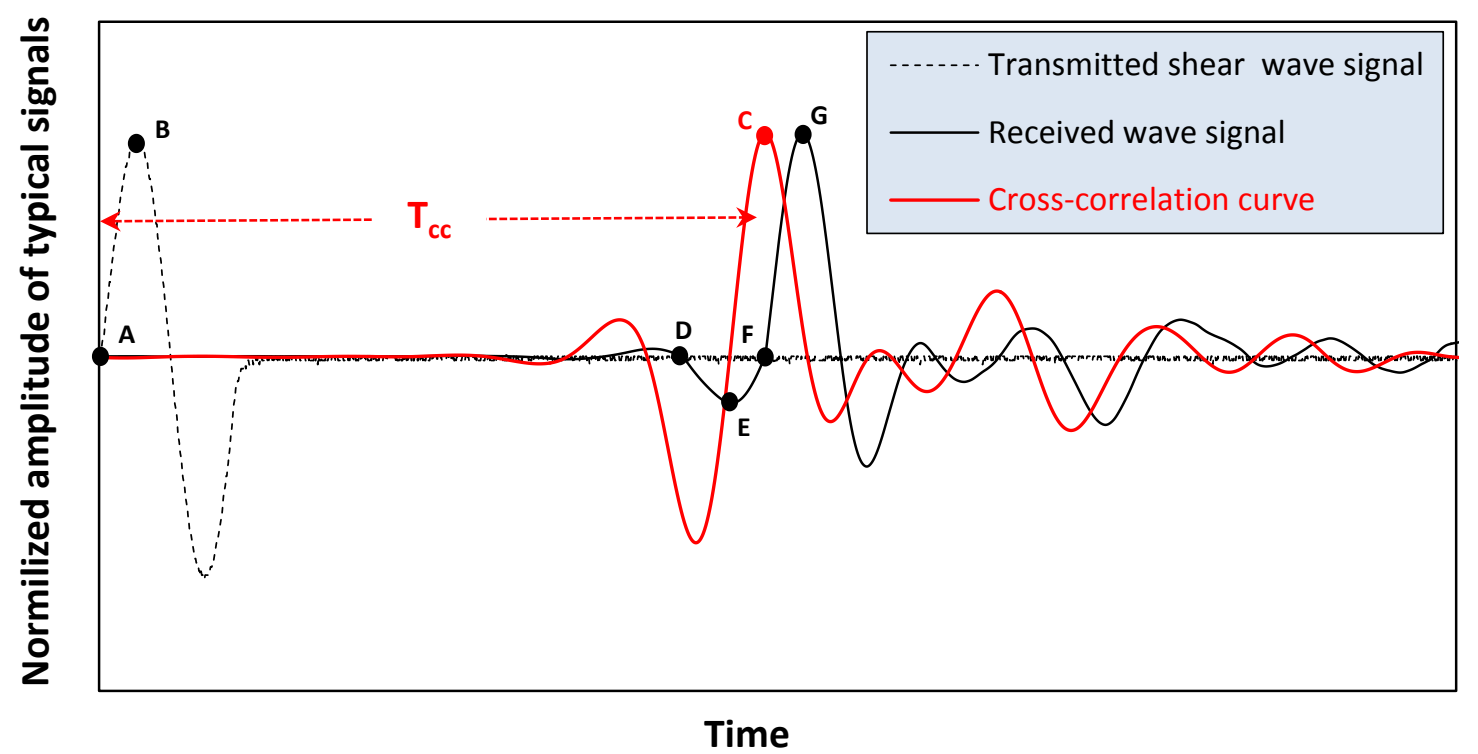

Fig. 6. Normalized signals of typical shear transmitted wave and the received one along with the resultant cross-correlation curve 
(a)

\section{Ottawa sand}

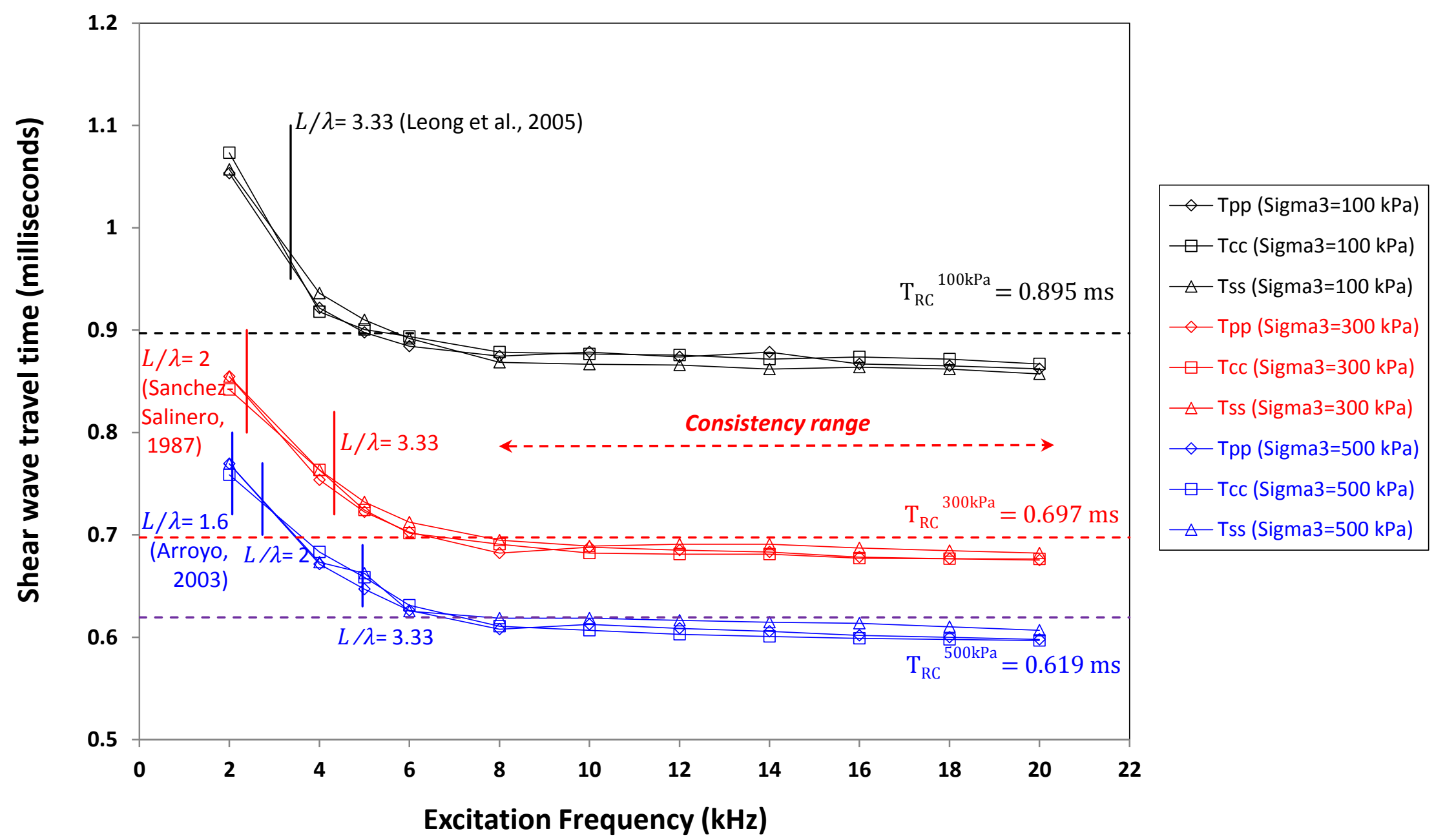


(b)

\section{Firoozkooh sand}

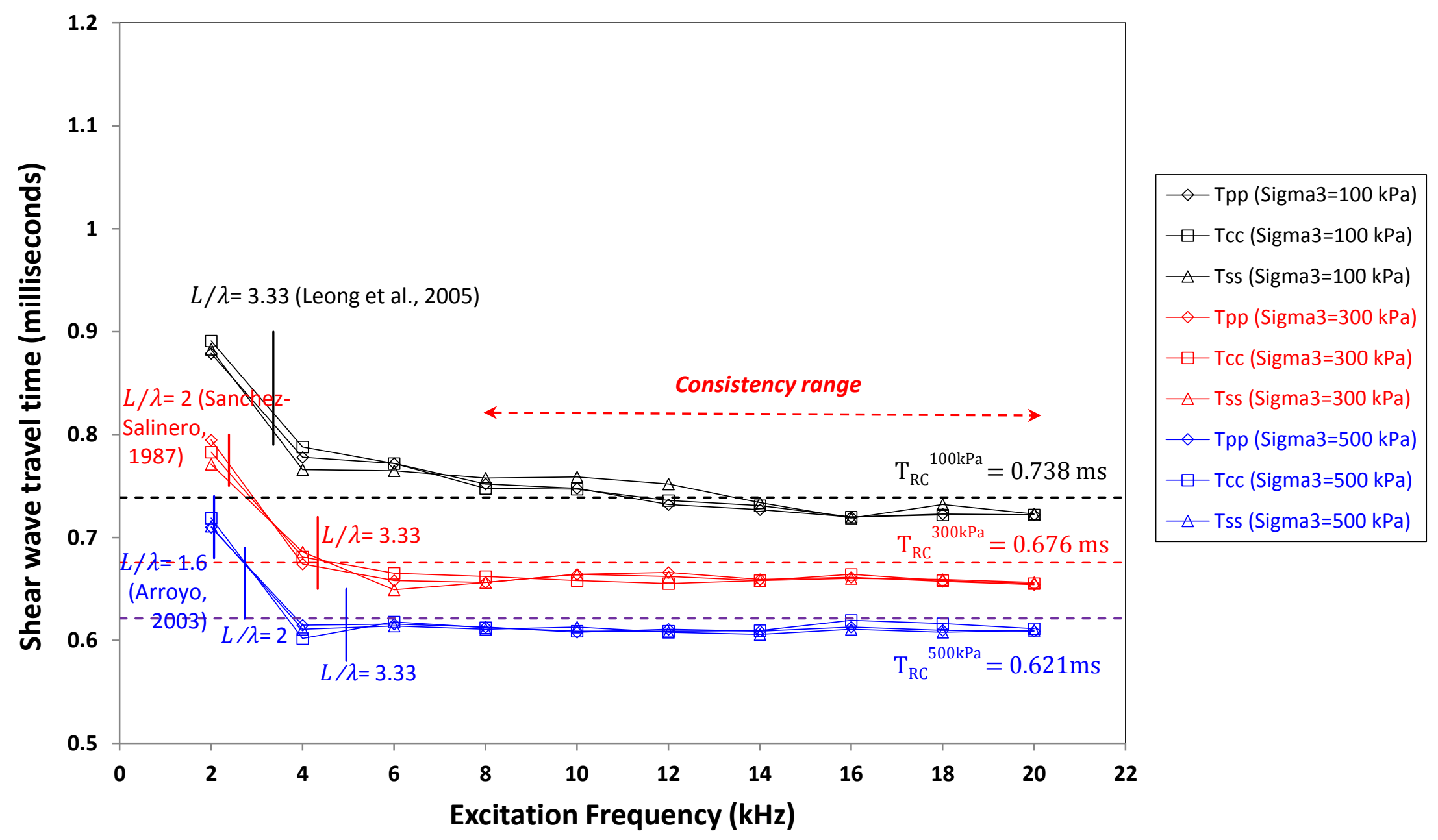

Fig. 7. Shear wave travel time (ms) measured by start-to-start, peak-to-peak, cross-correlation and resonant column test for oven-dried

(a) Ottawa and (b) Firoozkooh sand $\left(\mathrm{e}_{0}=0.715\right)$ 

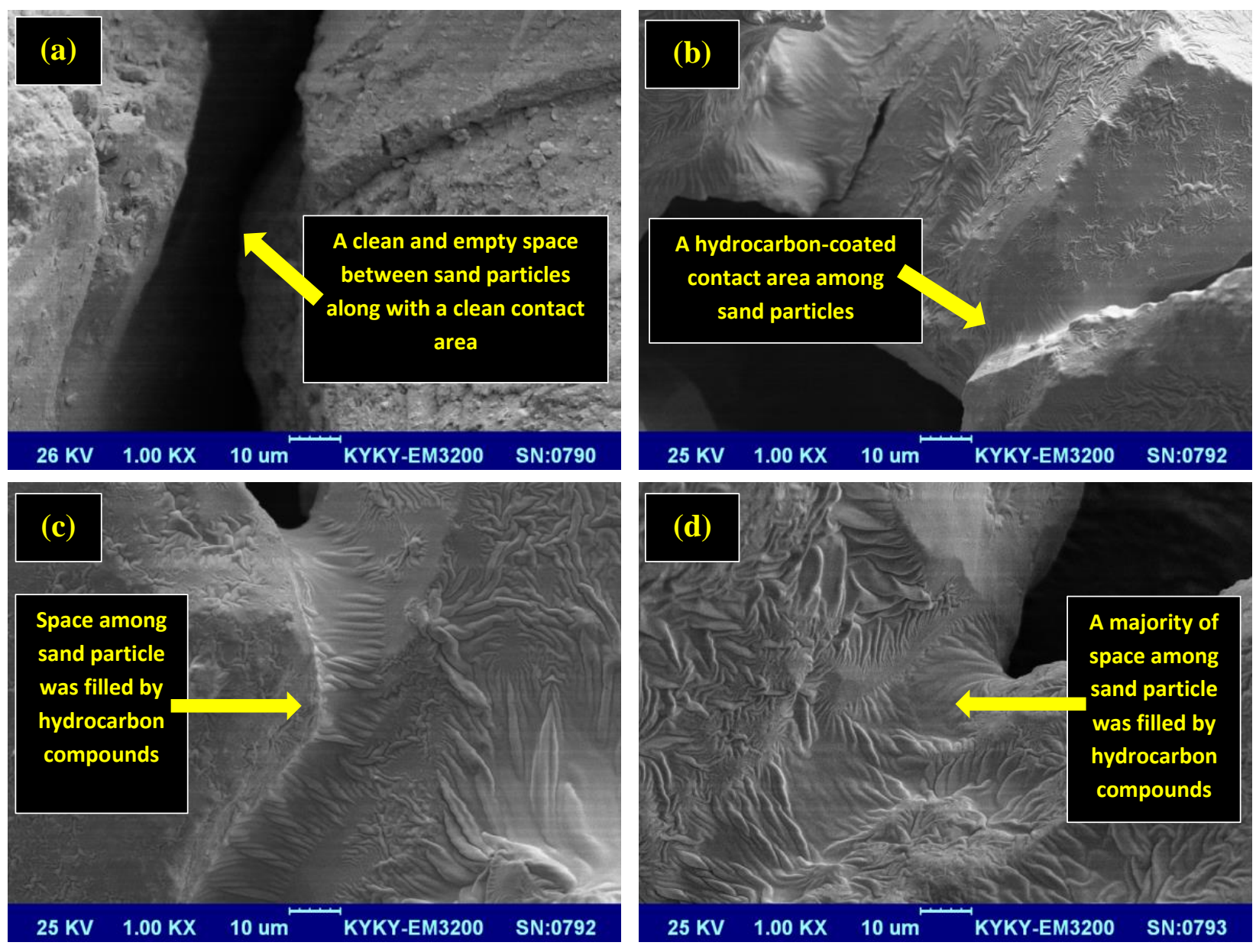

Fig. 8. SEM images of (a) clean oven-dried, (b) 4 wt.\% crude oil contaminated, (c) 8 wt.\% crude oil contaminated, and (d) 12 wt.\% crude oil contaminated Ottawa sand captured at 26000 Volt with scale bar of $10 \mathrm{um}$ and magnification of $1.00 \mathrm{KX}$ 

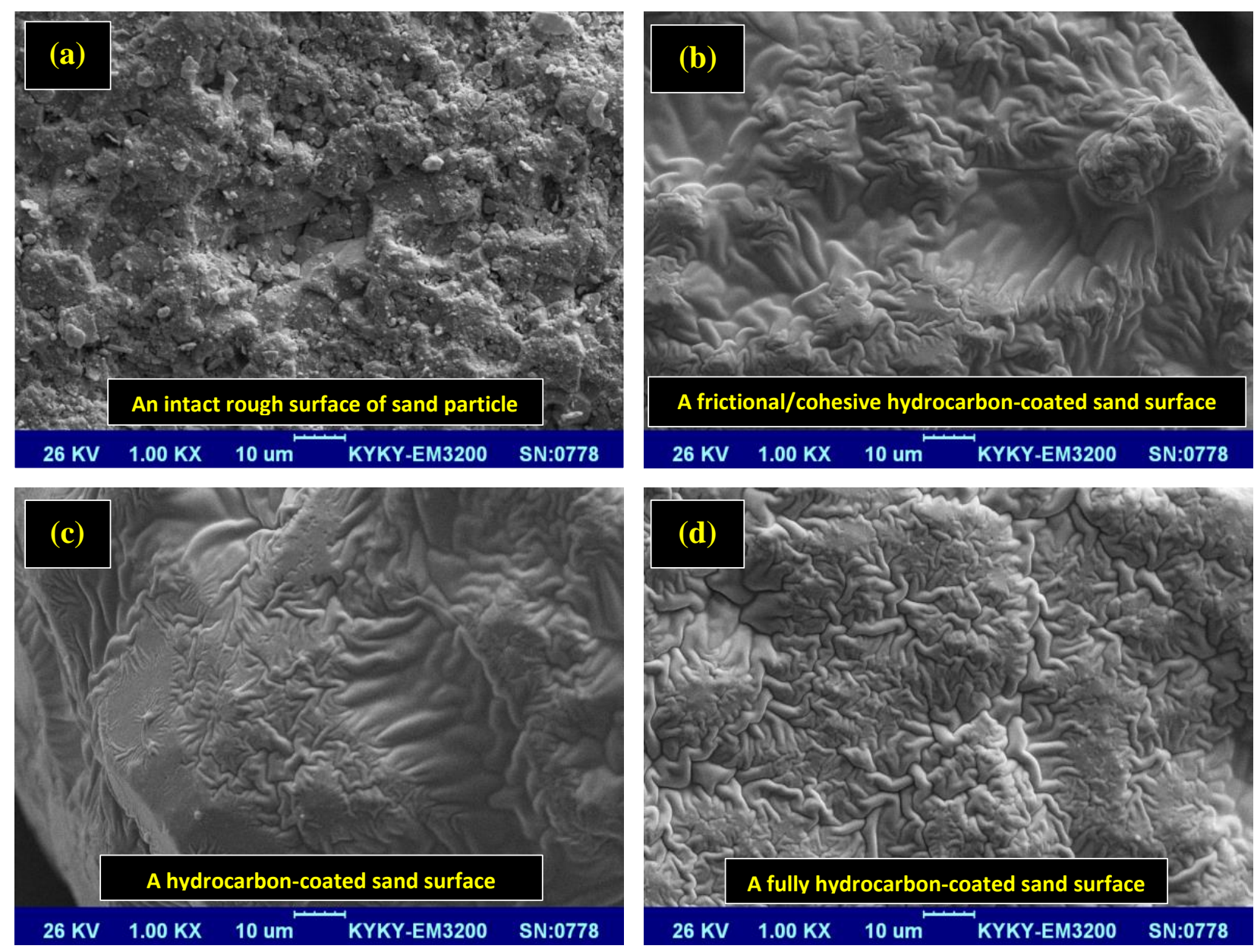

Fig. 9. SEM images of (a) clean oven-dried, (b) 4 wt.\% crude oil contaminated, (c) 8 wt.\% crude oil contaminated, and (d) 12 wt.\% crude oil contaminated Firoozkooh sand captured at 26000 Volt with scale bar of $10 \mathrm{um}$ and magnification of $1.00 \mathrm{KX}$ 


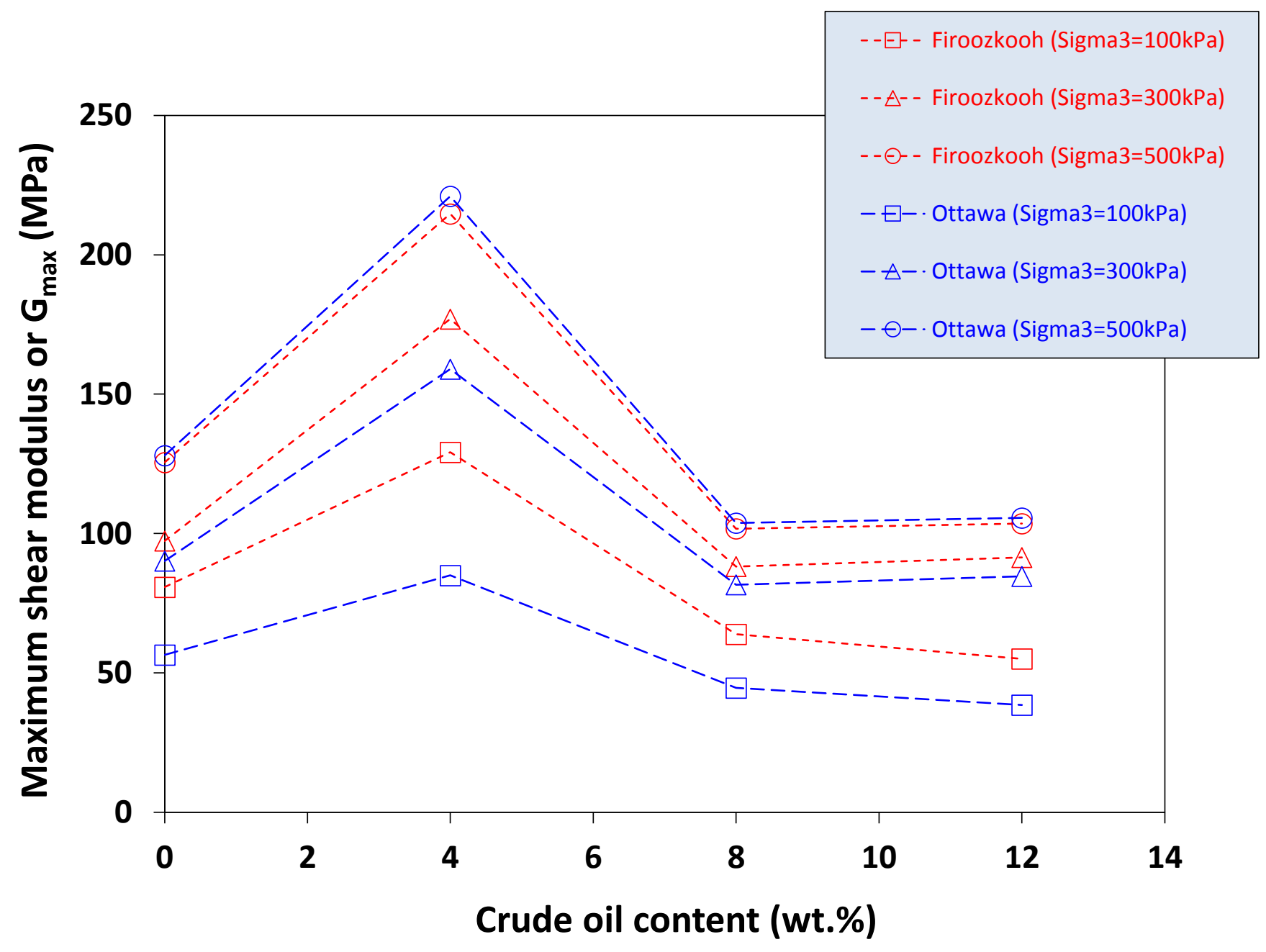

Fig. 10. Maximum shear modulus (MPa) of clean and contaminated Ottawa and Firoozkooh sand with various crude oil contents $(4,8$, and $12 \mathrm{wt} . \%)$ and $\mathrm{e}_{0}=0.715$ at frequency of $15 \mathrm{kHz}$ 
(a)

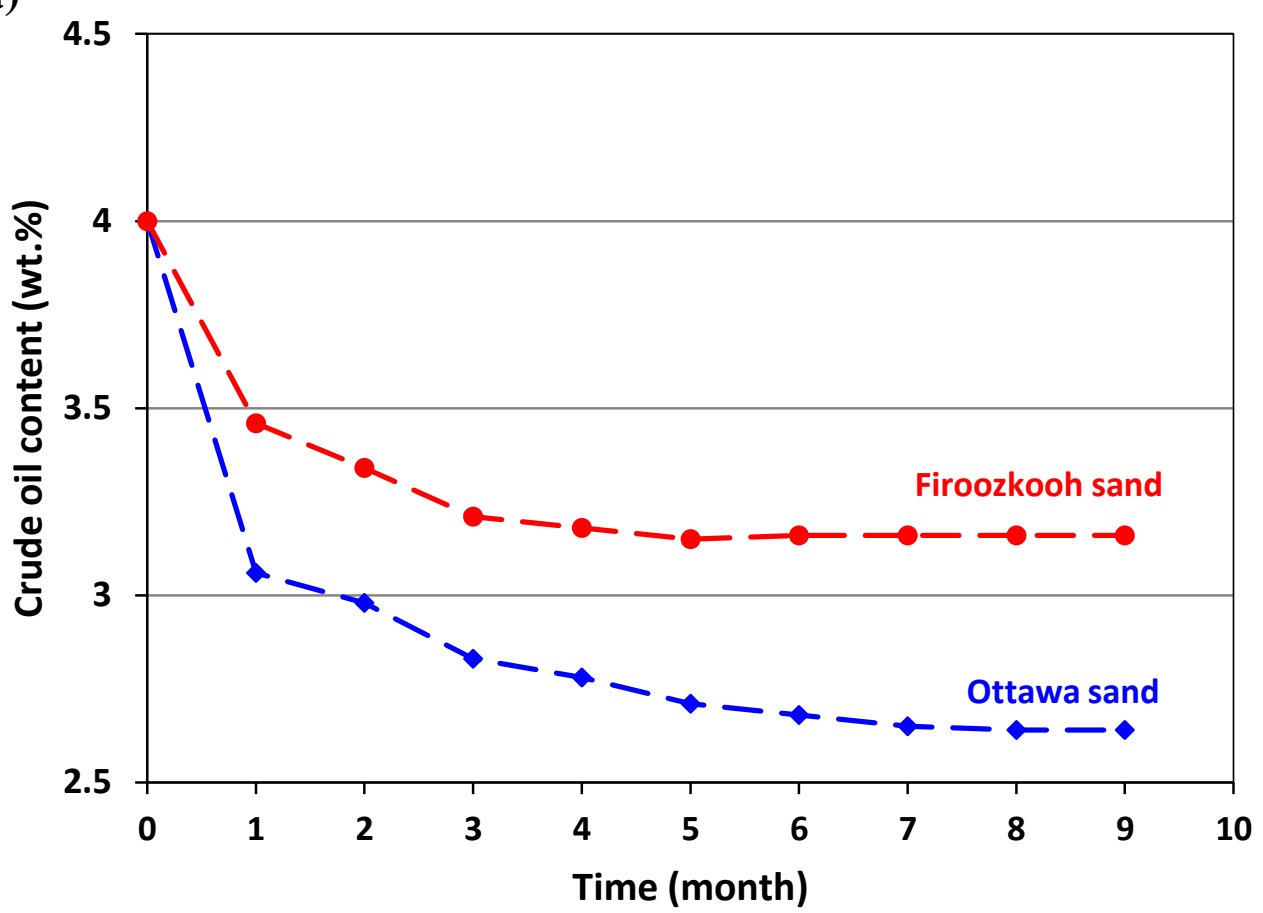

(b)

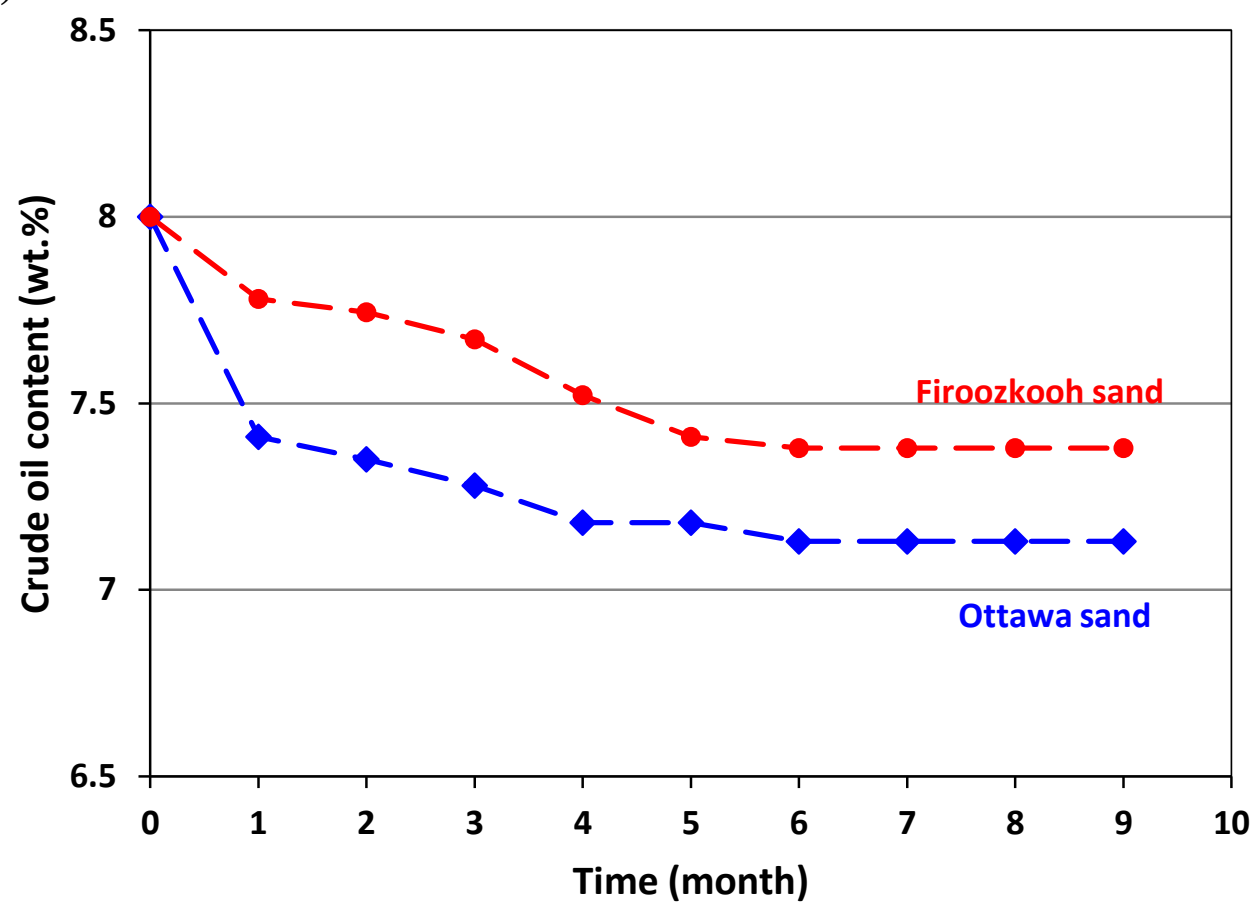


(c)

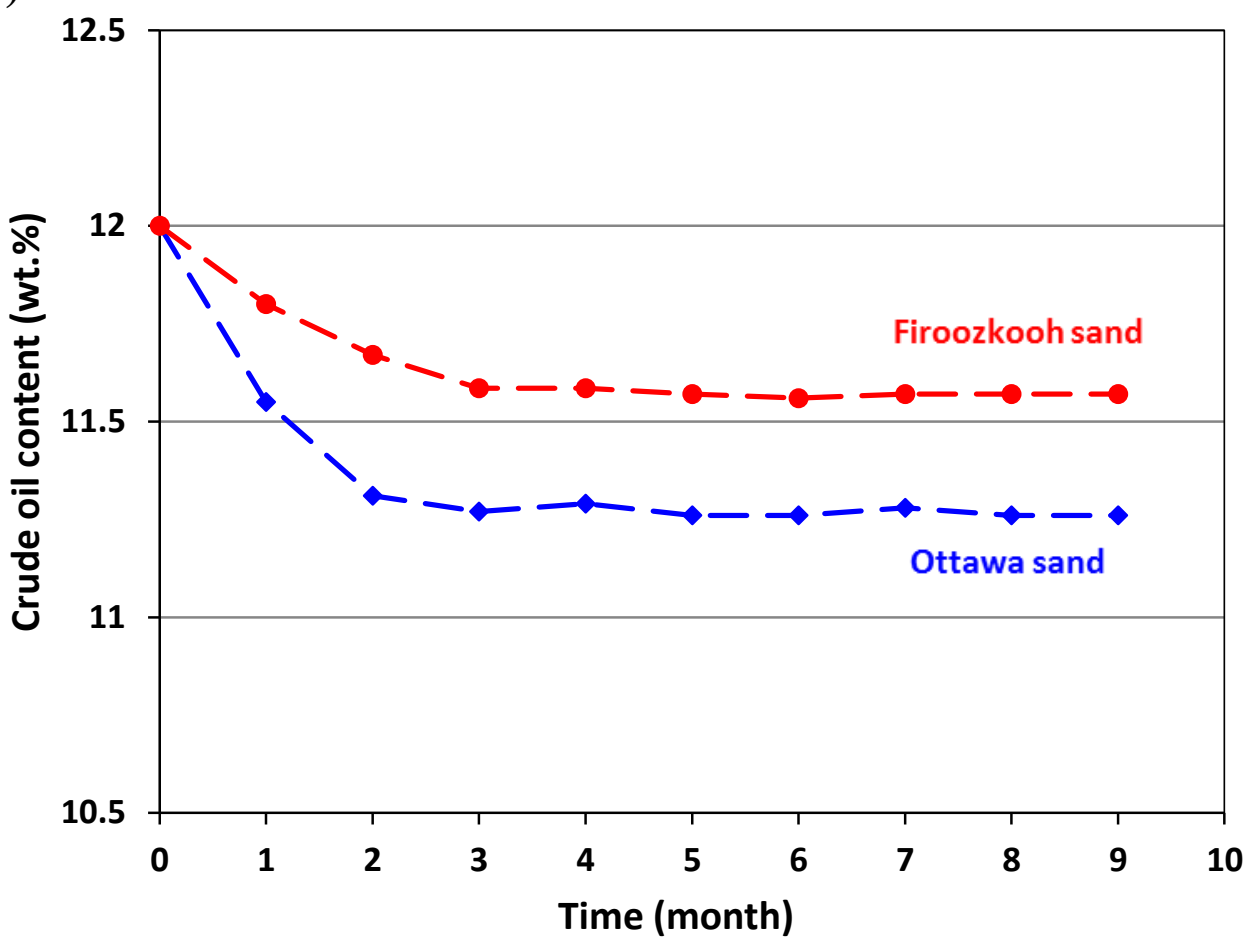

Fig. 11. The remained crude oil (wt.\%) in both types of contaminated sand with (a) 4 wt. \%, (b) 8 wt.\%, (c) 12 wt.\% of light crude oil 

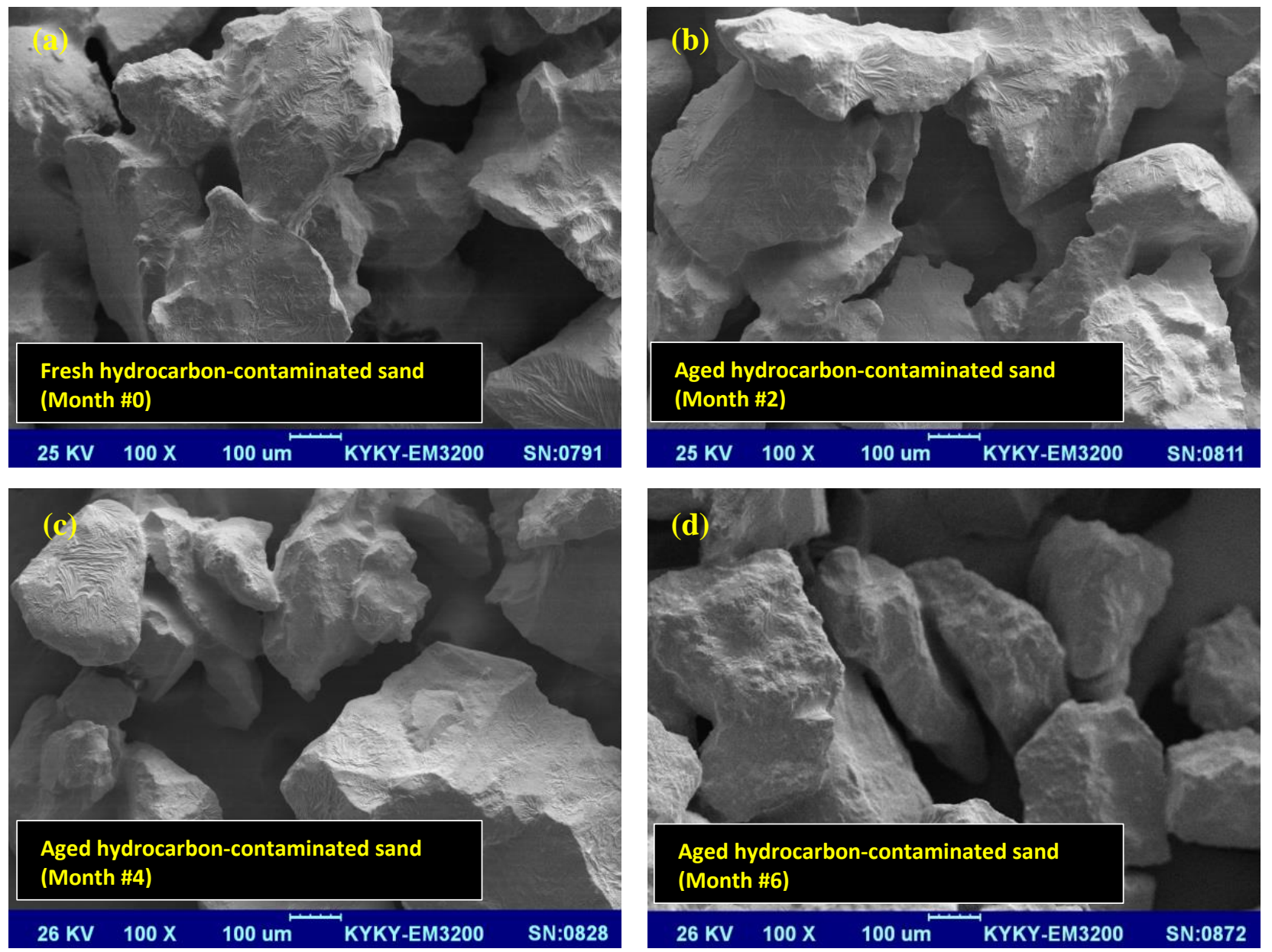

Fig. 12. SEM images of 4 wt.\% crude oil contaminated Ottawa sand in the status of (a) fresh (month \#0), (b) 2 months after contamination (month \#2), (c) 4 months after contamination (month \#4), and (d) 6 months after contamination (month \#6) captured at 26000 Volt with scale bar of $100 \mathrm{um}$ and magnification of $100 \mathrm{X}$ 


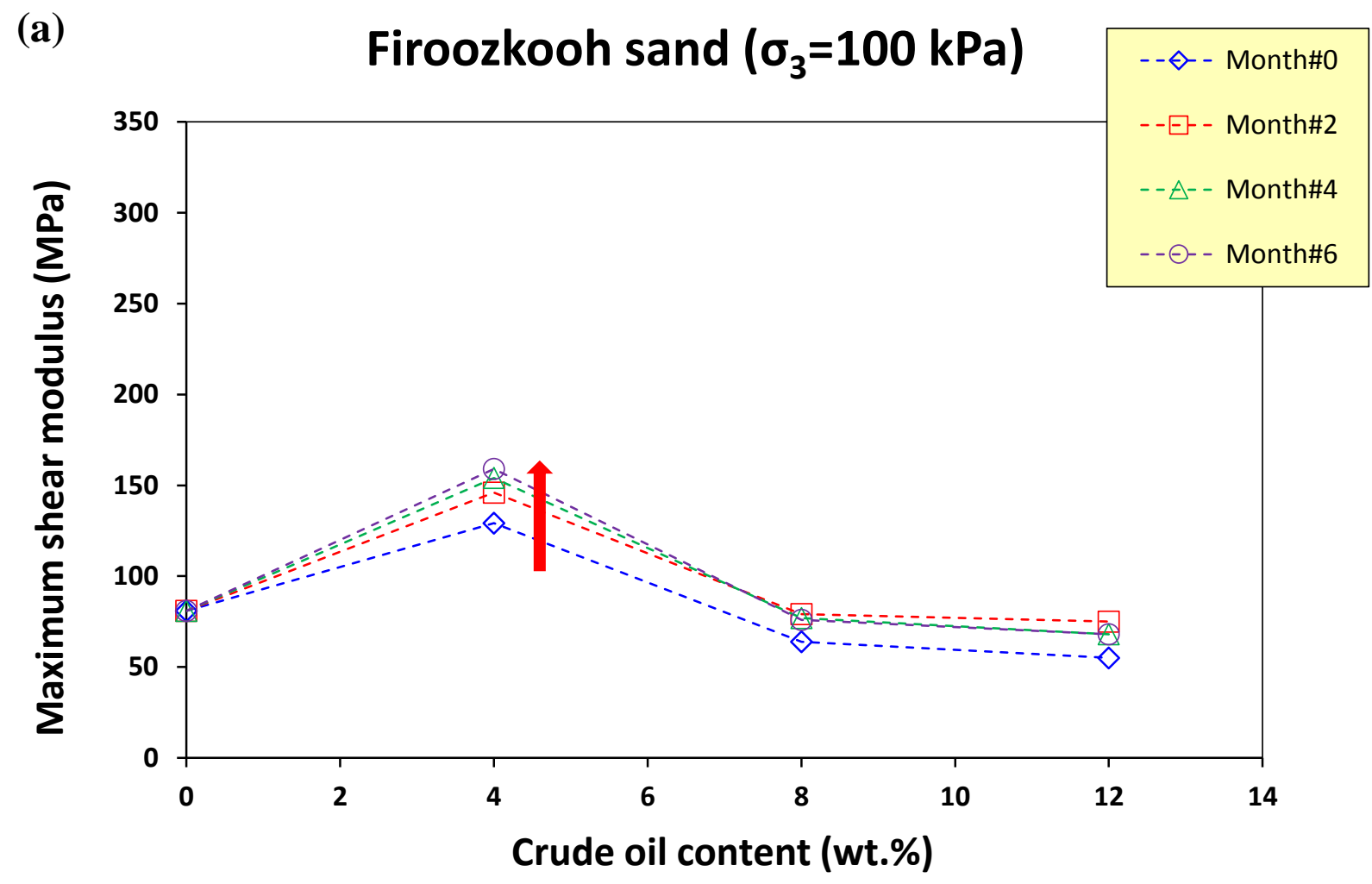

(b)

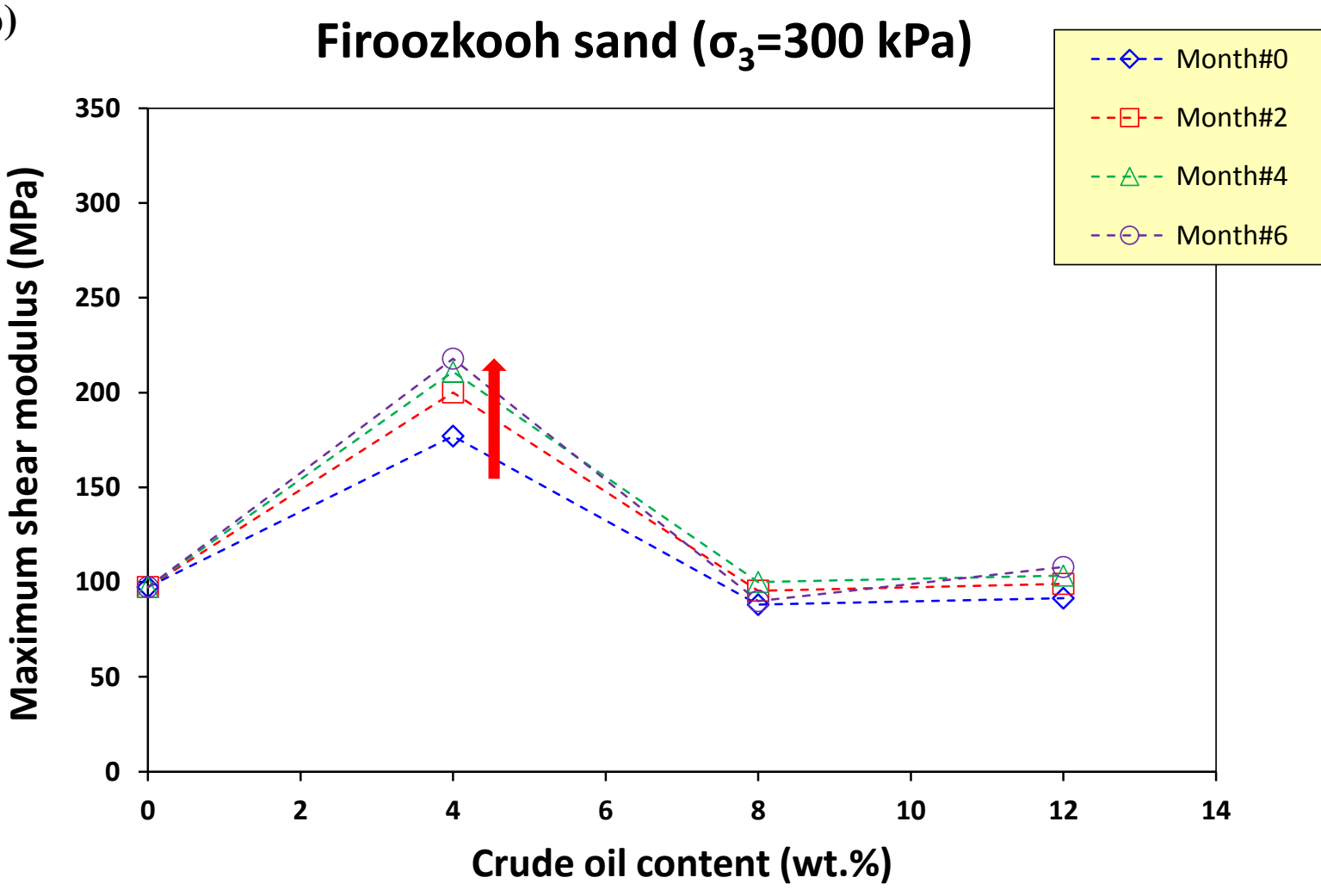




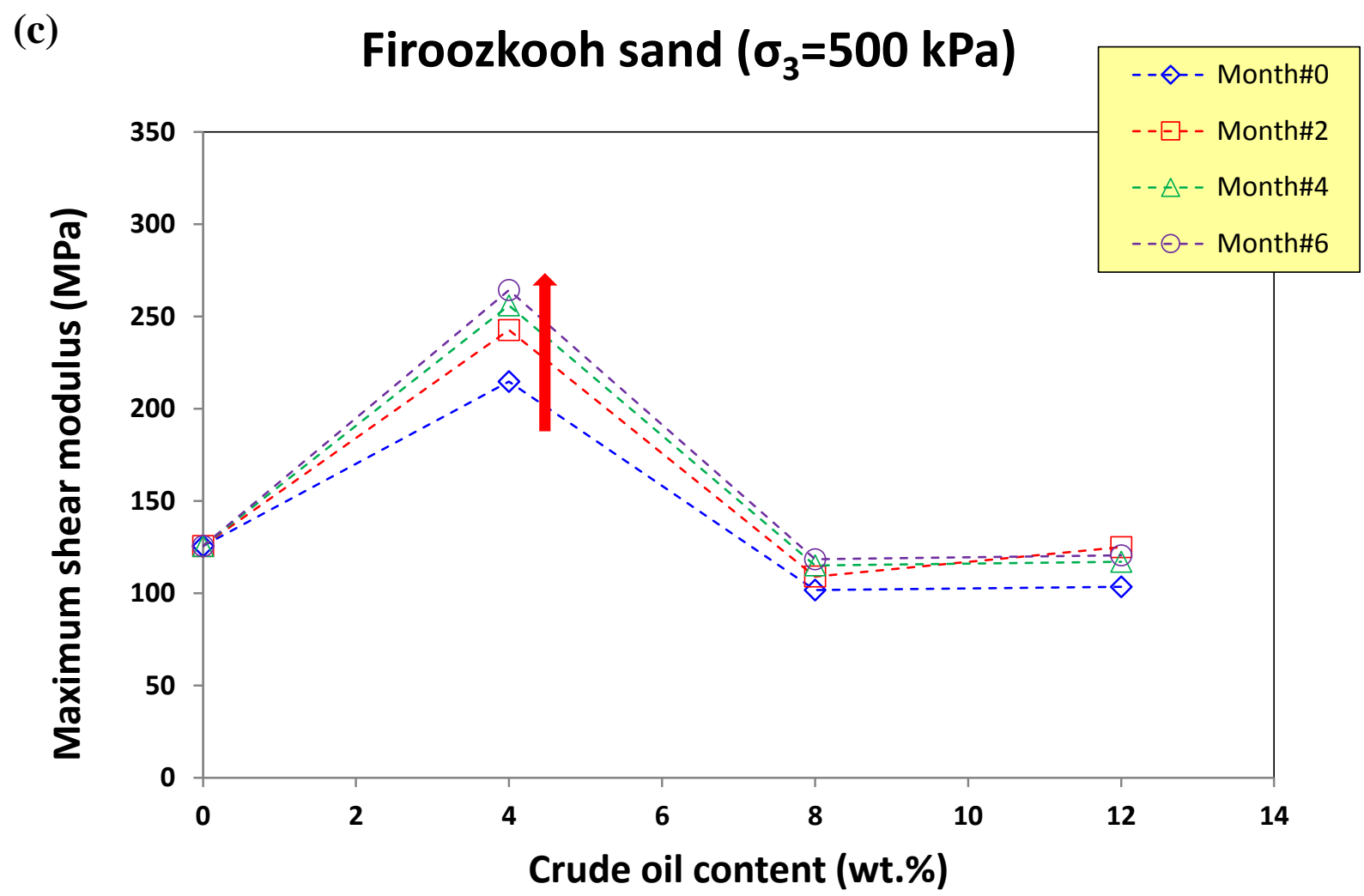

Fig. 13. $G_{\max }$ of the aged contaminated Firoozkooh sand under various confining pressures of (a) $100 \mathrm{kPa}$, (B) $300 \mathrm{kPa}$, and (C) $500 \mathrm{kPa}$ 


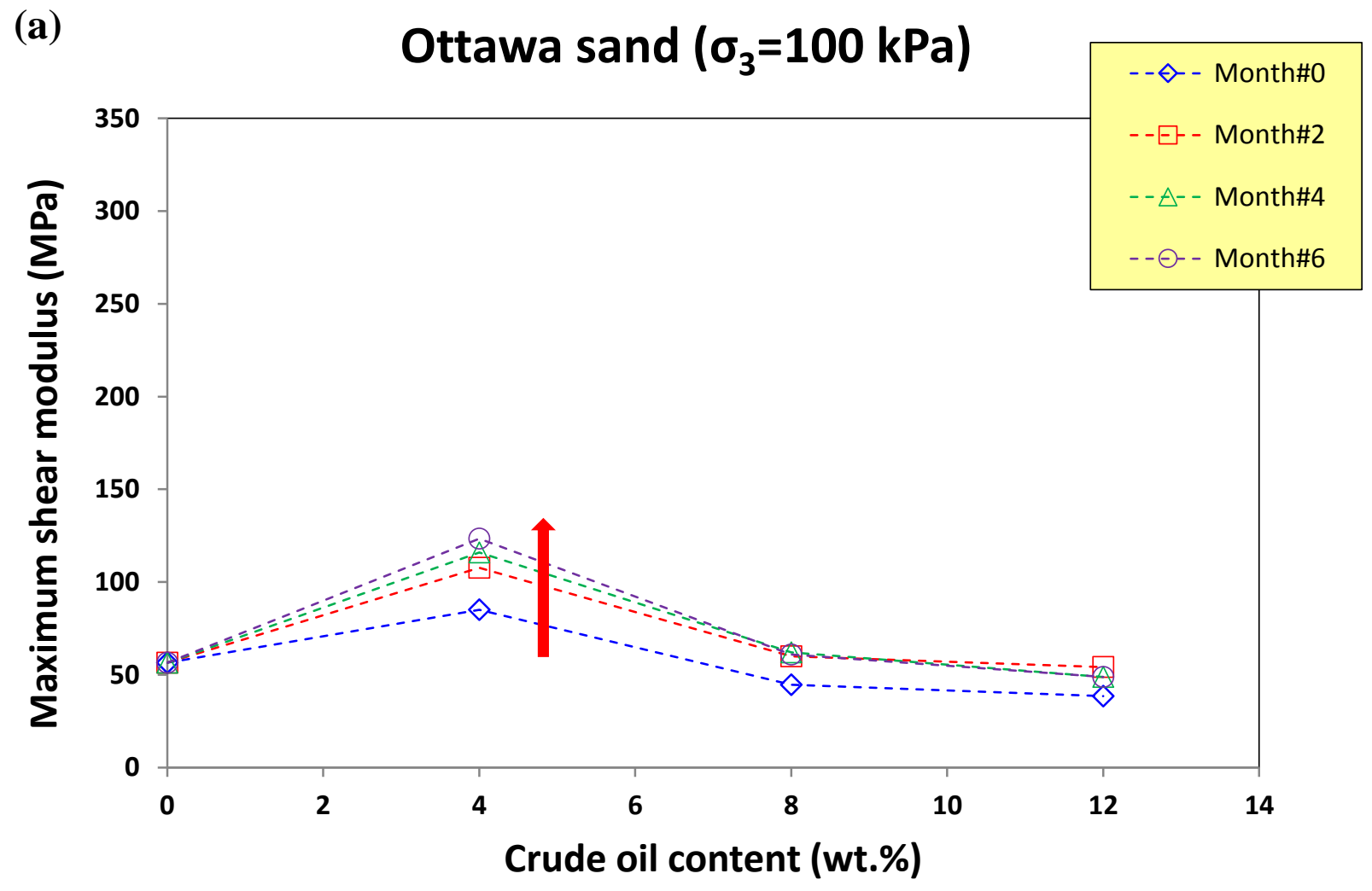




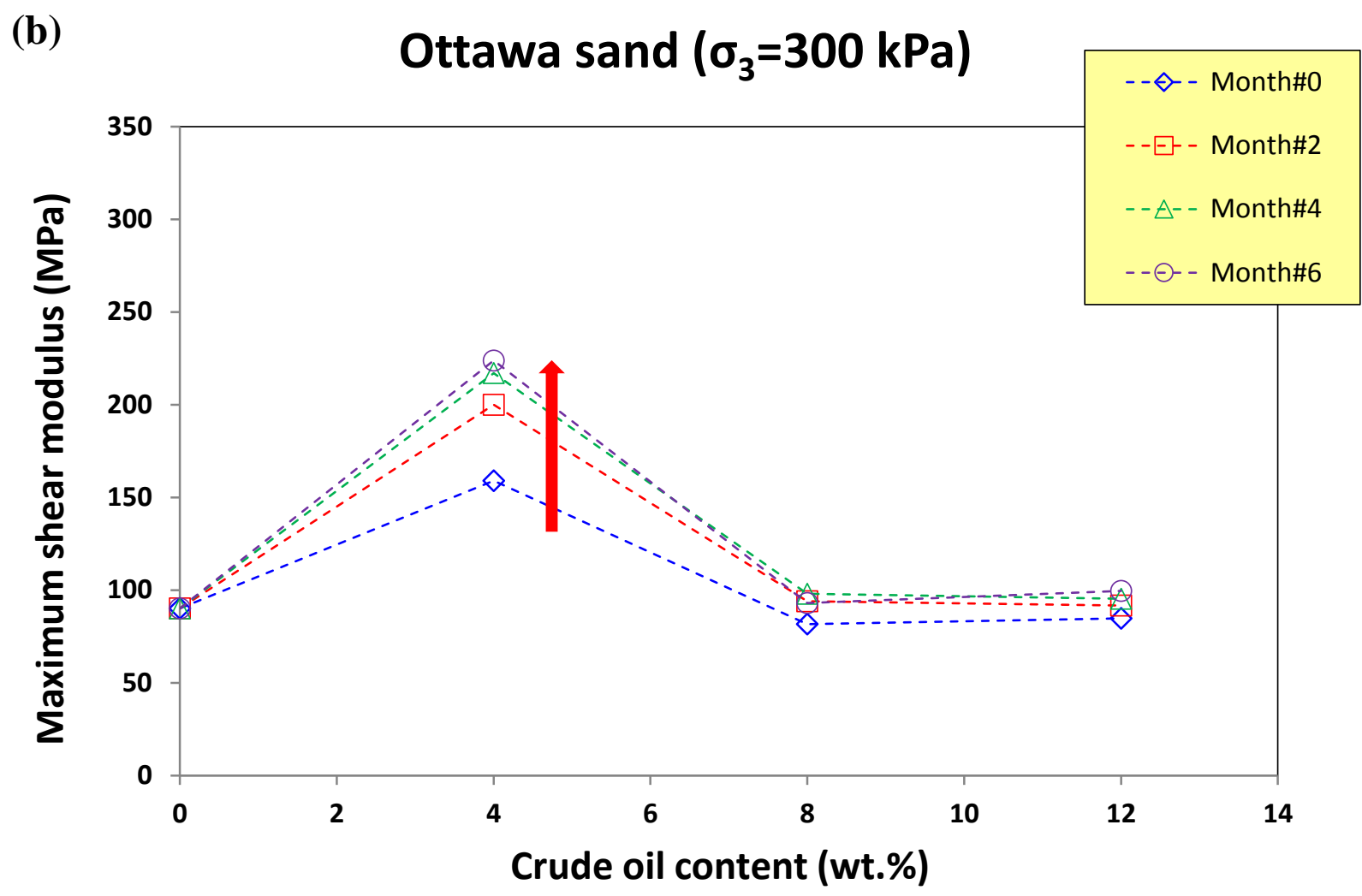




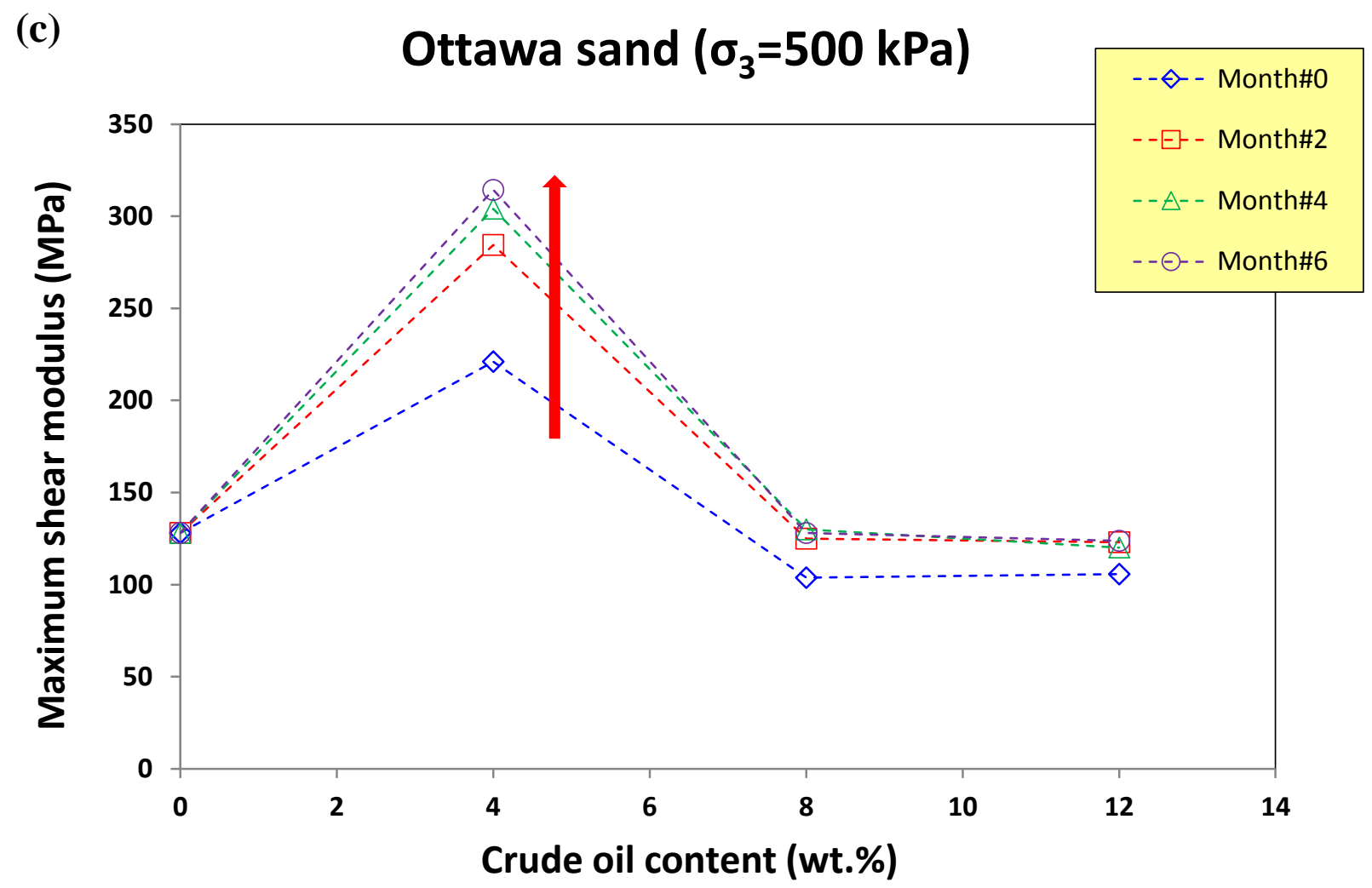

Fig. 14. $G_{\text {max }}$ of aged contaminated Ottawa sand under various confining pressures of (a) 100 $\mathrm{kPa}$, (B) $300 \mathrm{kPa}$, and (C) $500 \mathrm{kPa}$ 